University of Nebraska - Lincoln

DigitalCommons@University of Nebraska - Lincoln

3-28-2019

\title{
Flow alteration-ecology relationships in Ozark Highland streams: Consequences for fish, crayfish and macroinvertebrate assemblages
}

Dustin T. Lynch

Douglas R. easure

Daniel D. Magoulick

Follow this and additional works at: https://digitalcommons.unl.edu/usgsstaffpub

Part of the Geology Commons, Oceanography and Atmospheric Sciences and Meteorology Commons, Other Earth Sciences Commons, and the Other Environmental Sciences Commons

This Article is brought to you for free and open access by the US Geological Survey at DigitalCommons@University of Nebraska - Lincoln. It has been accepted for inclusion in USGS Staff -- Published Research by an authorized administrator of DigitalCommons@University of Nebraska - Lincoln. 


\title{
Flow alteration-ecology relationships in Ozark Highland streams: Consequences for fish, crayfish and macroinvertebrate assemblages is
}

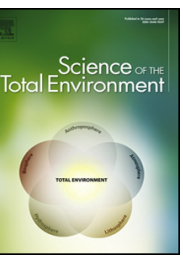

\author{
Dustin T. Lynch ${ }^{\mathrm{a}, *}$, Douglas R. Leasure ${ }^{\mathrm{b}}$, Daniel D. Magoulick ${ }^{\mathrm{c}}$ \\ a Arkansas Natural Heritage Commission, Department of Arkansas Heritage, 1100 North Street, Little Rock, AR 72201, USA \\ b Department of Geography and Environment, University of Southampton, Highfield, Southampton, SO17 1BJ, UK, United Kingdom

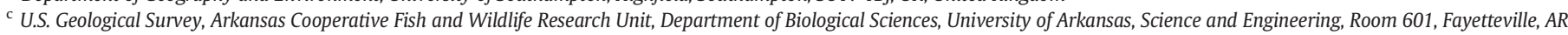 \\ 72701, USA
}

\section{H I G H L I G H T S}

- Flow alteration-ecological response relationships vary temporally.

- Relationships also vary between taxonomic assemblages within the same community.

- Flow magnitude and frequency are the categories of alteration that affect most taxa.

- The majority of important flow metrics are altered relative to expected values.

- Effective conservation of stream communities depends on complex suite of variables.

\section{A R T I C L E I N F O}

\section{Article history:}

Received 20 September 2018

Received in revised form 19 March 2019

Accepted 24 March 2019

Available online 28 March 2019

Editor: Henner Hollert

\section{Keywords:}

Flow alteration

Environmental flows

Hydrology

Fish

Crayfish

Macroinvertebrates

\section{G R A P H I C A L A B S T R A C T}

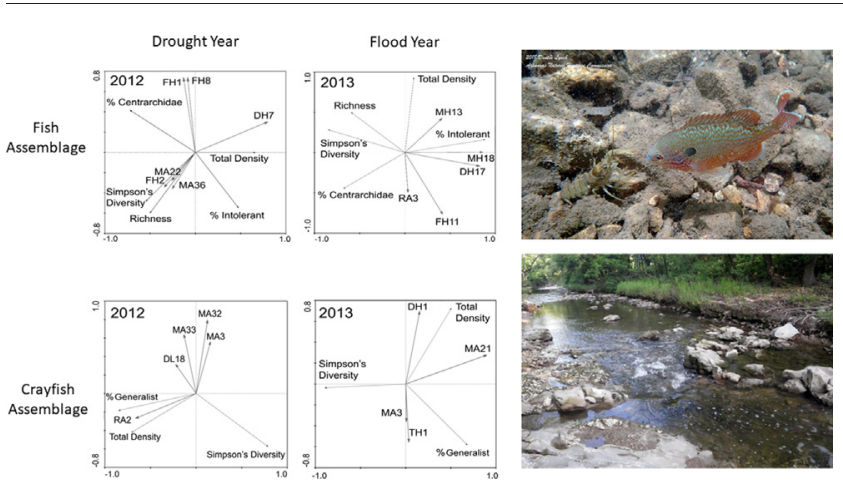

\begin{abstract}
A B S T R A C T
We examined flow alteration-ecology relationships in benthic macroinvertebrate, fish, and crayfish assemblages in Ozark Highland streams, USA, over two years with contrasting environmental conditions, a drought year (2012) and a flood year (2013). We hypothesized that: 1) there would be temporal variation in flow alteration-ecology relationships between the two years, 2) flow alteration-ecology relationships would be stronger during the drought year vs the flood year, and 3) fish assemblages would show the strongest relationships with flow alteration. We used a quantitative richest-targeted habitat (RTH) method and a qualitative multihabitat $(\mathrm{QMH})$ method to collect macroinvertebrates at 16 USGS gaged sites during both years. We used backpack electrofishing to sample fish and crayfish at 17 sites in 2012 and 11 sites in 2013 . We used redundancy analysis to relate biological response metrics, including richness, diversity, density, and community-based metrics, to flow alteration. We found temporal variation in flow alteration-ecology relationships for all taxa, and that relationships differed greatly between assemblages. We found relationships were stronger for macroinvertebrates during the drought year but not for other assemblages, and that fish assemblage relationships were not stronger than the invertebrate taxa. Magnitude of average flow, frequency of high flow, magnitude of high flow, and duration of high flow were the most important categories of flow alteration metrics across taxa. Alteration of high and average flows was more important than alteration of low flows. Of 32 important flow alteration metrics across years and assemblages, 19 were significantly altered relative to expected values. Ecological responses differed substantially between drought and flood years, and this is likely to be exacerbated with predicted climate
\end{abstract}

\footnotetext{
is This draft manuscript is distributed solely for the purposes of scientific peer review. Its content is deliberative and predecisional, so it must not be disclosed or released by reviewers. Because the manuscript has not yet been approved for publication by the U.S. Geological Survey (USGS), it does not represent any official USGS findings or policy.

* Corresponding author.

E-mail address: dustin.lynch@okstate.edu (D.T. Lynch).
} 
change scenarios. Differences in flow alteration-ecology relationships among taxonomic groups and temporal variation in relationships illustrate that a complex suite of variables should be considered for effective conservation of stream communities related to flow alteration.

(C) 2019 Elsevier B.V. All rights reserved.

\section{Introduction}

The natural flow regime paradigm posits that the ecological integrity of rivers depends on their natural dynamic character (Poff et al., 1997), and that traditional approaches to managing streams by simply focusing on minimum low flows may be inadequate to protect these ecosystems and their biota (Bunn and Arthington, 2002; Poff et al., 2010). A concept related to the natural flow regime is the environmental flow regime; the key difference is that environmental flow regimes allow for some degree of hydrologic alteration in an attempt to balance the needs of humans as well as stream ecosystems, while still resulting in the same patterns and ecological outcomes as the natural flow regime (Poff et al., 1997; Bunn and Arthington, 2002; Poff et al., 2010). One of the great challenges in the implementation of the environmental flows (eflows) approach to management and restoration is accounting for natural variability and complexity among different types of streams, even those within the same geographic region (Arthington et al., 2006; Kennard et al., 2010; Poff et al., 2010).

Natural streamflow regimes are threatened worldwide by a host of anthropogenic factors, including construction of dams and diversion structures, groundwater withdrawals from aquifers, and other hydromorphological alterations (Sondergaard and Jeppesen, 2007; Carlisle et al., 2010). Additionally, extreme climate events are expected to increase as a result of global climatic change, including many events that directly impact lotic ecosystems, such as increases in drought frequency, duration, and intensity in many regions of the world (Beniston et al., 2007; Beche et al., 2009), including in the focal region of this study, where these phenomena have already had consequences for rare and imperiled aquatic species (Magoulick and Lynch, 2015). The potential interactive effects of natural and anthropogenic stressors such as drought, climate change, and human water use on ecosystems highlight the need for increased understanding of each stressor (Christensen et al., 2006; Beche et al., 2009). For example, water withdrawals during dry years can reduce habitat connectivity and result in critical flow reductions (Beche et al., 2009). The maintenance of natural hydrologic regimes can also provide resistance to species invasion (Closs and Lake, 1996; Caiola et al., 2014), another pervasive world-wide phenomenon in freshwater habitats, often facilitated by anthropogenic alteration of flow regimes (Bunn and Arthington, 2002). For example, naturally flashy streams or rivers typified by frequent or rapid onset of high flows can prevent the establishment of non-native fish species that lack behavioral adaptations to rapid onset of flows (Meffe, 1984; Poff et al., 2010) or have a vulnerable juvenile stage present during periods of peak flows (Fausch et al., 2001; Poff et al., 2010).

Quantifying flow alteration, the degree of variation away from the natural flow regime, is a crucial step in environmental-flows based management approaches such as the ELOHA framework (Poff et al., 2010; Kendy et al., 2012; Gillespie et al., 2014; McManamay and Frimpong, 2015; King et al., 2015; Sengupta et al., 2018). While there is strong evidence that flow alteration generally negatively affects biodiversity as well as ecosystem function (Bunn and Arthington, 2002; Harris and Heathwaite, 2011; Warfe et al., 2014), there are challenges to establishing transferable relationships between flow alteration and ecological response (Poff and Zimmerman, 2010). Crucial steps in the ELOHA process include regional flow regime classification and the quantification of flow alteration; these steps are often made difficult by lack of hydrological data due to the somewhat sparse nature of stream gages, which are often placed only on larger order stream segments and may not represent all stream types in an area (Zimmerman et al., 2018). Determining quantifiable relationships between hydrologic alteration and biological data is not only of great interest in informing management decisions relating to issues of water conservation and restoration (McManamay et al., 2014), but could potentially also be a critical tool in the assessment of the possible impacts of climate change on stream ecosystems and organisms (Xenopolous et al., 2005; Farjad et al., 2015).

The objective of this study was to examine flow alteration-biological response relationships for fish, crayfish, and benthic macroinvertebrate assemblages in the Ozark Highlands. We hypothesized that: 1) there would be temporal variation in flow alteration-ecology relationships between the two years (drought year versus flood year), 2) flow alteration-ecology relationships would be stronger during the drought year vs the flood year, and 3) fish assemblages would show the strongest relationships with flow alteration.

We hypothesized that the potential interactive effects between the dual stressors of drought and flow alteration would lead to stronger relationships during the drought year (Acuna et al., 2005; Beche et al., 2009; Bunn and Arthington, 2002; Dodds et al., 2004; Poff and Allan, 1995; Lynch et al., 2018). We hypothesized that fish would be more strongly impacted by drought than the other groups due to the ability of benthic macroinvertebrates and crayfish to utilize the hyporheic zone as a refuge (DiStefano et al., 2009; Wood et al., 2010; Stubbington, 2012) or to utilize drought-coping life history strategies ranging from aestivation (Wickson et al., 2012) and desiccation-resistant eggs (Pallares et al., 2016) to overland escape (Chester et al., 2014) or shifts in timing of emergence (Stenroth et al., 2010). To address our objectives, we conducted aquatic community sampling at 18 sites in Groundwater Flashy streams in the Ozark Highlands over two years and used redundancy analysis (RDA) to relate biological response variables to metrics of flow alteration, including magnitude, frequency, duration, timing, and rate of change.

\subsection{Study area}

The Ozark Highlands ecoregion of southern Missouri, northern Arkansas, and northeast Oklahoma, USA (Omernik and Griffith, 2014), is heavily affected by a suite of anthropogenic impacts, including rapid development of urban areas and agricultural practices that affect water quality (Petersen et al., 2005; Haggard, 2010; Scott et al., 2011), expansion of natural gas extraction (Johnson et al., 2015), displacement of native fauna due to the spread of invasive species (Magoulick and DiStefano, 2007; Larson et al., 2009), and direct hydrologic alteration of streams via construction of reservoirs and dams (TNC-OEAT, 2003). This region is home to a diverse assortment of freshwater habitats and aquatic species, including endemic fish, crayfish, mussels, macroinvertebrates, and herpetofauna (TNCOEAT, 2003). Understanding the impacts of hydrologic alteration could be a crucial step in the formulation of guidelines for protection and restoration of stream ecosystems in the region.

\section{Methods}

\subsection{Site selection}

Sampling was conducted at 18 sites with USGS stream gages over two summer field seasons (May-July) during 2012 and 2013 in northwest 


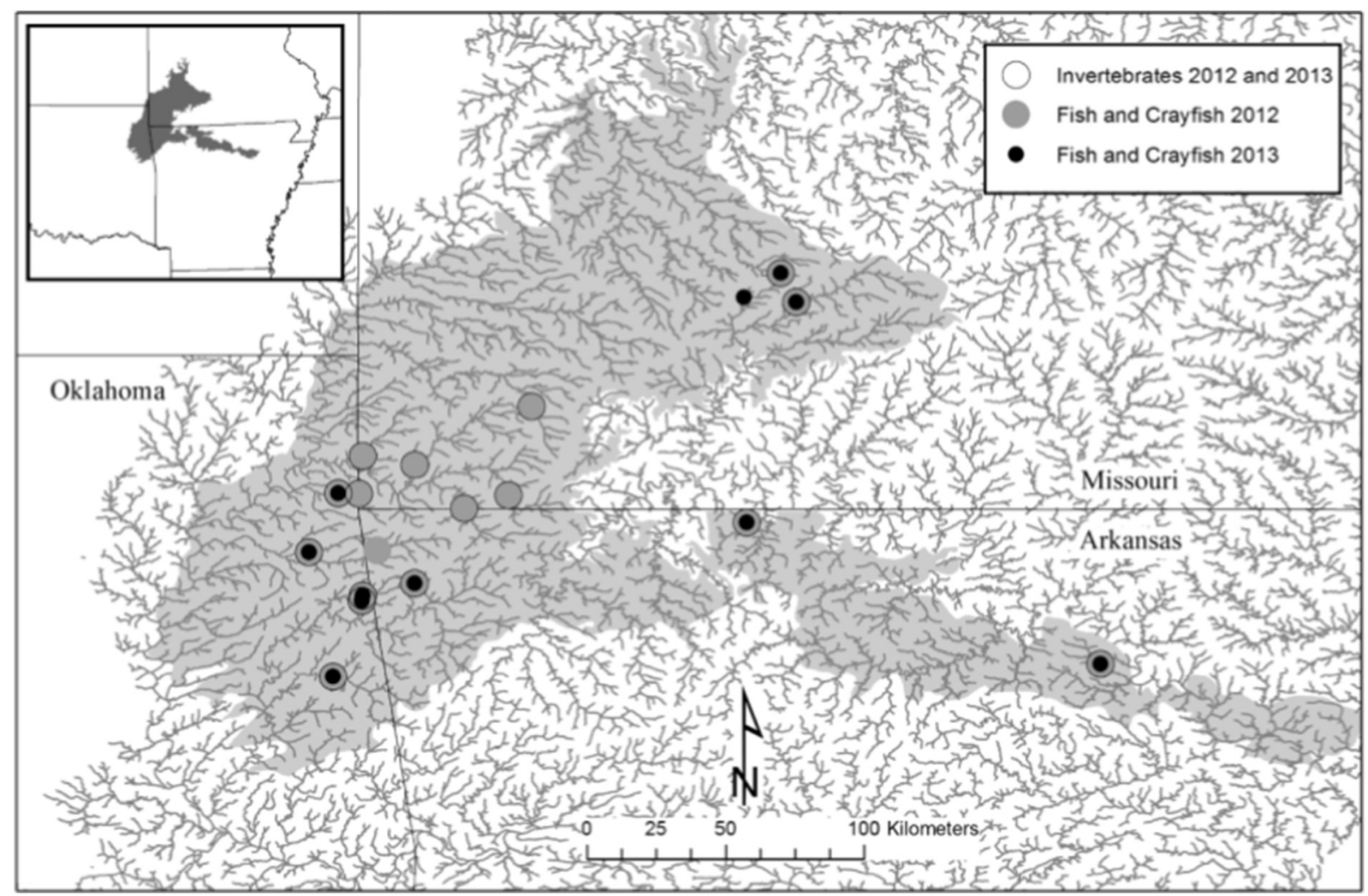

Fig. 1. Map of study area showing sample sites, stream network, and Springfield Plateau (shaded area).

Arkansas, southwest Missouri, and northeast Oklahoma (Fig. 1). Precipitation and flow conditions contrasted strongly between the two years. In summer 2012 the study area experienced an extreme drought, as measured on the Palmer Drought Severity Index (Palmer, 1965), while sustained higher than normal precipitation resulted in summer flooding at most sites during 2013 (NOAA, 2015). To facilitate biological comparisons, site selection was limited to a single ecoregion, the Ozark Highlands, a single physiographic region, the Springfield Plateau, and a single flow regime, Groundwater Flashy streams, based on a classification of Ozark-Ouachita Interior Highland streams into seven different hydrologic flow regimes (Leasure et al., 2016). Streams selected ranged in drainage area from 16 to $542 \mathrm{~km}^{2}$.

Macroinvertebrate collections were taken at 16 sites that were the same in both years (Fig. 1). Due to extreme differences in sampling conditions between the two years (drought in 2012 versus extensive flooding in 2013), we were unable to resample seven of the largest sites from the first field season for fish and crayfish during the second season, but did add one additional site. Seventeen sites were sampled for fish and crayfish in 2012 and 11 in 2013, with 10 overlapping sites between the two years (Fig. 1).

\subsection{Hydrologic variable and flow alteration estimation}

We identified 64 USGS gaged streams in our study area in leastdisturbed reference condition based on a composite hydrologic disturbance index (Falcone et al., 2010) using water withdrawals, density of major dams, change in dam storage between 1950 and 2009, percent canals in the watershed, water discharge locations, road density, and land cover fragmentation (Leasure et al., 2016). All streams selected in least-disturbed condition had an index less than the median of all gaged streams in the study area (Leasure et al., 2016). Using these streams, we developed a set of random forest models to predict 171 flow metrics (Olden and Poff, 2003). Full models were built initially that included 282 predictor variables describing climate, geology, soils, topography, groundwater and landscape characteristics within reference watersheds (Appendix A). Importance of each variable was assessed using the default method of the randomForest $\mathrm{R}$ package (Liaw and Wiener, 2002) that is based on how much prediction error increases when each variable is permuted while others are left the same. A benefit of using random forest models for this approach is that they are not sensitive to the number of variables at each node or the number of trees (Liaw and Wiener, 2002). A reduced model was built for each flow metric that included only the 30 most important predictor variables.

Data were collected at all 208 USGS gages in the Interior Highlands for any predictor variable selected for at least one of the reduced random forest models. The reduced random forest models were used to predict values of each flow metric expected under natural conditions, as well as the distribution of expected values. The expected value for each flow metric under natural conditions was taken as the median of the predicted distribution.

Flow metrics were calculated for every complete 15 year period within the daily flow records of 18 gages used in this study. Flow alteration was calculated as:

flow alteration $=\frac{\text { observed }- \text { median }(\text { predicted })}{\text { std.dev }(\text { predicted })}$

where observed is the value of the flow metric from a specific period with a gage's record, and predicted is the distribution of values expected under natural conditions predicted by the random forest models. The standard deviation (std. dev) of predicted natural values was used for standardization rather than the interquartile range because the interquartile range may be zero for random forest models with high accuracy. We decided not to assess flow alteration as observed/expected as recommended by Carlisle et al. (2010) because of issues arising when expected values are zero. We dropped flow metrics that were outside 
our threshold criteria for bias, precision and accuracy, reducing our initial set of 171 metrics to 154 (Appendix B).

\subsection{Aquatic community assessment}

Benthic macroinvertebrates, fish, and crayfish were sampled at each site. Reaches were defined by the presence of at least three discrete units of riffles, runs, and pools, and a qualitative attempt was made to ensure that sampling reaches were as comparable as possible between sites. Sampling was stratified by habitat to include three units each of riffles, runs and pools for a total of nine units per reach. Total area of reaches ranged from 140 to $957 \mathrm{~m}^{2}$ and units averaged $8.3 \mathrm{~m}$ (SD = 3.2) in length across all habitat types. Habitat units were located at least $100 \mathrm{~m}$ from road crossings to avoid the hydrologic influence of man-made structures that could affect stream habitat (Barbour et al., 1999).

Benthic macroinvertebrate samples were typically collected at sites a few hours prior to fish and crayfish sampling. Macroinvertebrates were sampled using two different, complementary methods at each site, a semi-quantitative richest-targeted habitat (RTH) method and a qualitative multiple habitat $(\mathrm{QMH})$ method, both developed for the U.S. Geological Survey National Water Quality Assessment (NAWQA) program (Moulton et al., 2002). Quantitative RTH collections were taken in riffles using a 500- $\mu \mathrm{m}$ mesh Slack sampler $(50 \mathrm{~cm} \times 30 \mathrm{~cm})$ equipped with a $0.25 \mathrm{~m}^{2}$ area PVC frame attached to the upstream end of the sampler (Moulton et al., 2002). The Slack sampler was positioned immediately downstream of the chosen quadrat perpendicular to the direction of flow. Large cobble and woody debris were lightly brushed, inspected for any remaining invertebrates, and then removed from the sampling area. The sampling area was then agitated by disturbing the substrate upstream of the mouth of the sampler, allowing the dislodged invertebrates to flow into the trailing net. The nine discrete subsamples were composited into a 19-L plastic bucket for processing, which consisted of rinsing and removing large debris from the samples, followed by elutriation and sieving (with a $500 \mu \mathrm{m}$ sieve) in order to separate invertebrates and organic debris from inorganic material.

The QMH method was used to document invertebrate taxa present in all habitat types throughout the reach (Moulton et al., 2002). Crew members assessed the entire reach to determine the number of different instream habitat types present and to estimate the proportion of each type. QMH samples were collected using a D-frame kicknet with $500-\mu \mathrm{m}$ mesh. Each habitat type was sampled in proportion to total habitat area for a standardized time of $1 \mathrm{~h}$ per reach. Samples were processed in the field as described for the RTH method.

In the laboratory, RTH and QMH samples were sorted on a square gridded subsampling frame of $255 \times 5 \mathrm{~cm}$ squares using a fixedcount approach targeting a minimum of 300 organisms (Barbour et al., 1999; Moulton et al., 2000). After pouring the sample into the frame and allowing it to settle evenly, an initial inspection was performed to remove large and rare organisms likely to be missed during subsampling. A grid square was randomly selected and all organisms present were removed from the grid and processed. Subsampling proceeded in this fashion until a minimum of 300 organisms were counted, with the square in which the 300th organism was counted also fully processed. Macroinvertebrates were identified to the lowest practical taxonomic level, generally family or genus. To estimate total numbers of organisms, a laboratory subsampling correction factor was used (Moulton et al., 2000) in which the total number of grids was divided by the number of grids sorted during subsampling and multiplied by the number of organisms subsampled. Large and rare organisms taken from the sample as a whole were added to these numbers without a correction factor. These numbers were then used to calculate invertebrate community response metrics.

Fish and crayfish were collected using a Smith-Root Model LR-24 backpack-electrofishing unit which has been shown effective for fish and crayfish sampling in Ozark streams (Rabeni et al., 1997; Dauwalter and Pert, 2003). Standard LR-24 settings for power output based on ambient stream conductivity were used. Prior to sampling, $1.6 \mathrm{~cm}^{2}$ mesh block-nets were placed at the end of each habitat unit to prevent animals from escaping or biasing sampling data by moving from one unit to another. A four-person team conducted three upstream passes per habitat unit. Collections from all passes were kept in separate buckets until all passes were completed. Each pass was processed separately and all specimens were identified to species and released live back into the stream.

\subsection{Biological response metric selection}

Biological response metrics were calculated for macroinvertebrate, fish, and crayfish assemblages (Table 1). A subset of metrics considered most ecologically relevant was chosen based on published relationships and best professional judgment. The five macroinvertebrate response metrics chosen were: abundance; taxa richness; Simpson's diversity; percent contribution of individuals belonging to Orders Ephemeroptera, Plecoptera, and Trichoptera (EPT), taxa that are associated with undisturbed habitat and high water quality (Karr, 1991); and percent contribution of the family Chironomidae, considered a generally tolerant taxon predicted to increase in abundance with increasing levels of perturbation (Barbour et al., 1999). Response metrics calculated from RTH and QMH samples were analyzed separately.

For crayfish, the three response metrics chosen were: Simpson's diversity, total crayfish density (per volume sampled), and percent contribution of species designated as habitat generalists in an assessment of invasion risk of crayfish in the eastern United States (Larson and Olden, 2010). These are represented in our dataset by two species, Faxonius neglectus neglectus and Faxonius virilis. Species richness was not used as a community response metric for crayfish due to the generally low and relatively uniform richness across sites.

For fish, the five biological response metrics chosen were: species richness, Simpson's diversity, total fish density (per volume sampled), percent of total individuals belonging to Family Centrarchidae, and percent of total individuals belonging to species categorized as intolerant, i.e. sensitive to various environmental perturbation, in an Index of Biotic Integrity specifically developed for fish assemblages of the Ozark Highlands (Dauwalter et al., 2003). Percent Centrarchidae was chosen as a response metric because most Ozark centrarchids are ecologically tolerant habitat generalists (Dauwalter et al., 2003; Robison and Buchanan, 1988).

Table 1

Mean $( \pm$ SE) values for biological response metrics.

\begin{tabular}{lll}
\hline Variable & 2012 & 2013 \\
\hline RTH macroinvertebrate taxa richness & $22( \pm 1.48)$ & $19( \pm 1.09)$ \\
RTH macroinvertebrate Simpson's diversity & $0.81( \pm 0.03)$ & $0.77( \pm 0.02)$ \\
RTH macroinvertebrate \% EPT & $49.65( \pm 4.93)$ & $59.93( \pm 4.65)$ \\
RTH macroinvertebrate \% Chironomidae & $9.31( \pm 3.48)$ & $11.54( \pm 2.50)$ \\
RTH macroinvertebrate abundance & $2568( \pm 757.14)$ & $4064( \pm 809.97)$ \\
QMH macroinvertebrate taxa richness & $25( \pm 2.28)$ & $27( \pm 1.29)$ \\
QMH macroinvertebrate Simpson's diversity & $0.73( \pm 0.05)$ & $0.85( \pm 0.02)$ \\
QMH macroinvertebrate \% EPT & $22.67( \pm 0.04)$ & $33.94( \pm 0.04)$ \\
QMH macroinvertebrate \% Chironomidae & $6.33( \pm 0.03)$ & $17.46( \pm 2.94)$ \\
QMH macroinvertebrate abundance & $2710( \pm 799.82)$ & $3292( \pm 398.98)$ \\
Fish species richness & $16( \pm 0.94)$ & $15( \pm 1.15)$ \\
Fish Simpson's diversity & $0.73( \pm 0.03)$ & $0.73( \pm 0.04)$ \\
Fish \% intolerant & $70.35( \pm 4.21)$ & $71.56( \pm 4.03)$ \\
Fish \% Centrarchidae & $2.68( \pm 0.77)$ & $5.08( \pm 1.67)$ \\
Fish total density & $11.66( \pm 0.77)$ & $11.73( \pm 1.51)$ \\
Crayfish Simpson's diversity & $0.20( \pm 0.05)$ & $0.32( \pm 0.06)$ \\
Crayfish \% extraregional & $80.10( \pm 8.34)$ & $40.46( \pm 11.07)$ \\
Crayfish total density & $3.54( \pm 1.05)$ & $8.00( \pm 2.66)$ \\
\hline
\end{tabular}




\subsection{Data analysis}

Redundancy analysis (RDA) was used to evaluate flow alterationecology relationships separately for assemblages and sampling years. $\mathrm{RDA}$ is a canonical ordination procedure that examines relationships among response variables and predictor variables in multivariate space (ter Braak, 1995). Linear model RDA's were appropriate because preliminary Detrended Correspondence Analyses (DCA) indicated that species gradient lengths were $<1$ standard deviation (ter Braak, 1995). We used forward selection in CANOCO 4.5 (ter Braak and Smilauer, 2002) to select flow alteration variables that were related to response metrics. We limited the flow alteration variables to those with lambda $\geq 0.7$ after entry into the model.

Prior to RDA analysis, response variables were centered and standardized. Scaling of ordination scores was focused on inter-response variable correlations rather than inter-sample distances, and the response variable scores were standardized to prevent variables with large variances from disproportionately influencing ordination diagrams (ter Braak and Smilauer, 2002). Monte Carlo permutations were performed for each RDA to test the significance of the canonical axes together and were then performed for each RDA to determine the overall importance of remaining environmental variables in influencing response variables. Analyses of response variable-flow alteration relationships were performed separately for each year, taxonomic assemblage and sampling type (for macroinvertebrates). All significant hydrologic alteration metrics are listed and defined in Table 2. Percent variance explained in assemblage-environment relationships was examined by comparing eigenvalues from RDA analysis in order to test our second and third hypotheses.

\section{Results}

\subsection{RTH macroinvertebrates}

In 2012, RTH macroinvertebrate response metrics were significantly related to alteration of DH18, TA3, and RA3 (RDA $p<0.001$, Table 2, Fig. 2). RA3 was significantly reduced relative to expected values (Fig. 2). Diversity, richness, and percent EPT were all negatively related to alteration of TA3, while abundance and percent Chironomidae were

Table 2

Important hydrologic alteration metrics (Olden and Poff, 2003) used in RDA analysis for 2012 and 2013 with mean ( \pm SE) values.

\begin{tabular}{|c|c|c|c|}
\hline Code & Definition & Category & Mean $( \pm S E)$ \\
\hline \multicolumn{4}{|c|}{2012 RTH macroinvertebrates } \\
\hline DH18 & High flow duration (upper threshold 3 times median flows) & Duration of high flows & $-0.41( \pm 0.22)$ \\
\hline TA3 & Seasonal predictability of flooding & Timing of average flows & $1.20( \pm 0.59)$ \\
\hline RA3 & Fall rate & Rate of change of average flows & $-0.13( \pm 0.05)$ \\
\hline \multicolumn{4}{|c|}{2013 RTH macroinvertebrates } \\
\hline MA22 & Mean November flows & Magnitude of average flows & $-0.27( \pm 0.05)$ \\
\hline FH3 & High flood pulse count (upper threshold 3 times median daily flow) & Frequency of high flows & $-0.95( \pm 0.24)$ \\
\hline DH23 & Flood duration (mean annual number of days that flow remains above threshold averaged over all years) & Duration of high flows & $-0.27( \pm 0.16)$ \\
\hline TH2 & Variability in Julian date of annual maximum & Timing of high flows & $-1.06( \pm 0.57)$ \\
\hline \multicolumn{4}{|c|}{2012 QMH macroinvertebrates } \\
\hline MA12 & Mean January flows & Magnitude of average flows & $-0.16( \pm 0.06)$ \\
\hline ML12 & Mean minimum December flows & Magnitude of low flows & $0.13( \pm 0.04)$ \\
\hline MH3 & Mean maximum March flows & Magnitude of high flows & $-0.14( \pm 0.06)$ \\
\hline MH20 & Specific mean annual maximum flows (maximum flows divided by catchment area) & Magnitude of high flows & $0.01( \pm 0.27)$ \\
\hline FH11 & Flood frequency (mean number of discrete flood events per year) & Frequency of high flows & $-0.56( \pm 0.32)$ \\
\hline \multicolumn{4}{|c|}{2013 QMH macroinvertebrates } \\
\hline MA29 & Variability in June flows & Magnitude of average flows & $-0.74( \pm 0.21)$ \\
\hline MH17 & High flow discharge & Magnitude of high flows & $-0.58( \pm 0.15)$ \\
\hline FH4 & High flood pulse count (upper threshold 7 times median daily flow) & Frequency of high flows & $-0.72( \pm 0.20)$ \\
\hline FH5 & Flood frequency (upper threshold times median flow over all years) & Frequency of high flows & $1.08( \pm 0.68)$ \\
\hline DH23 & Flood duration (mean annual number of days that flow remains above threshold averaged over all years) & Duration of high flows & $-0.27( \pm 0.16)$ \\
\hline \multicolumn{4}{|c|}{2012 fish } \\
\hline MA22 & Mean November flows & Magnitude of average flows & $-0.29( \pm 0.05)$ \\
\hline MA36 & Variability across monthly flows & Magnitude of average flows & $-0.82( \pm 0.14)$ \\
\hline FH1 & High flood pulse count (pulse defined as 75th percentile) & Frequency of high flows & $-0.74( \pm 0.31)$ \\
\hline $\mathrm{FH} 2$ & Variability in high flood pulse count & Frequency of high flows & $-0.75( \pm 0.30)$ \\
\hline FH8 & Flood frequency (25th percentile upper threshold) & Frequency of high flows & $-0.73( \pm 0.32)$ \\
\hline DH7 & Variability in annual maxima of 3 day mean daily discharge & Duration of high flows & $-0.04( \pm 0.12)$ \\
\hline \multicolumn{4}{|c|}{2013 fish } \\
\hline MH13 & Variability across maximum monthly flows & Magnitude of high flows & $0.26( \pm 0.38)$ \\
\hline MH18 & Variability across annual maximum flows & Magnitude of high flows & $1.60( \pm 1.00)$ \\
\hline FH11 & Flood frequency (mean number of discrete flood events per year) & Frequency of high flows & $-0.18( \pm 0.41)$ \\
\hline DH17 & High flow duration (upper threshold 1 times median flows) & Duration of high flows & $-0.54( \pm 0.69)$ \\
\hline RA3 & Fall rate & Rate of change of average flows & $-0.11( \pm 0.09)$ \\
\hline \multicolumn{4}{|c|}{2012 crayfish } \\
\hline MA3 & Variability in daily flows & Magnitude of average flows & $-0.42( \pm 0.26)$ \\
\hline MA32 & Variability in September flows & Magnitude of average flows & $-0.51( \pm 0.2)$ \\
\hline MA33 & Variability in October flows & Magnitude of average flows & $-0.41( \pm 0.19)$ \\
\hline DL18 & Number of zero-flow days & Duration of low flows & $-0.18( \pm 0.13)$ \\
\hline RA2 & Variability in rise rate & Rate of change of average flows & $2.31( \pm 0.38)$ \\
\hline \multicolumn{4}{|c|}{2013 crayfish } \\
\hline MA3 & Variability in daily flows & Magnitude of average flows & $-0.85( \pm 0.32)$ \\
\hline MA21 & Mean October flows & Magnitude of average flows & $-0.01( \pm 0.06)$ \\
\hline DH1 & Annual maxima of daily mean discharge & Duration of high flows & $-0.24( \pm 0.08)$ \\
\hline TH1 & Julian date of annual maximum & Timing of high flows & $0.55( \pm 0.22)$ \\
\hline
\end{tabular}



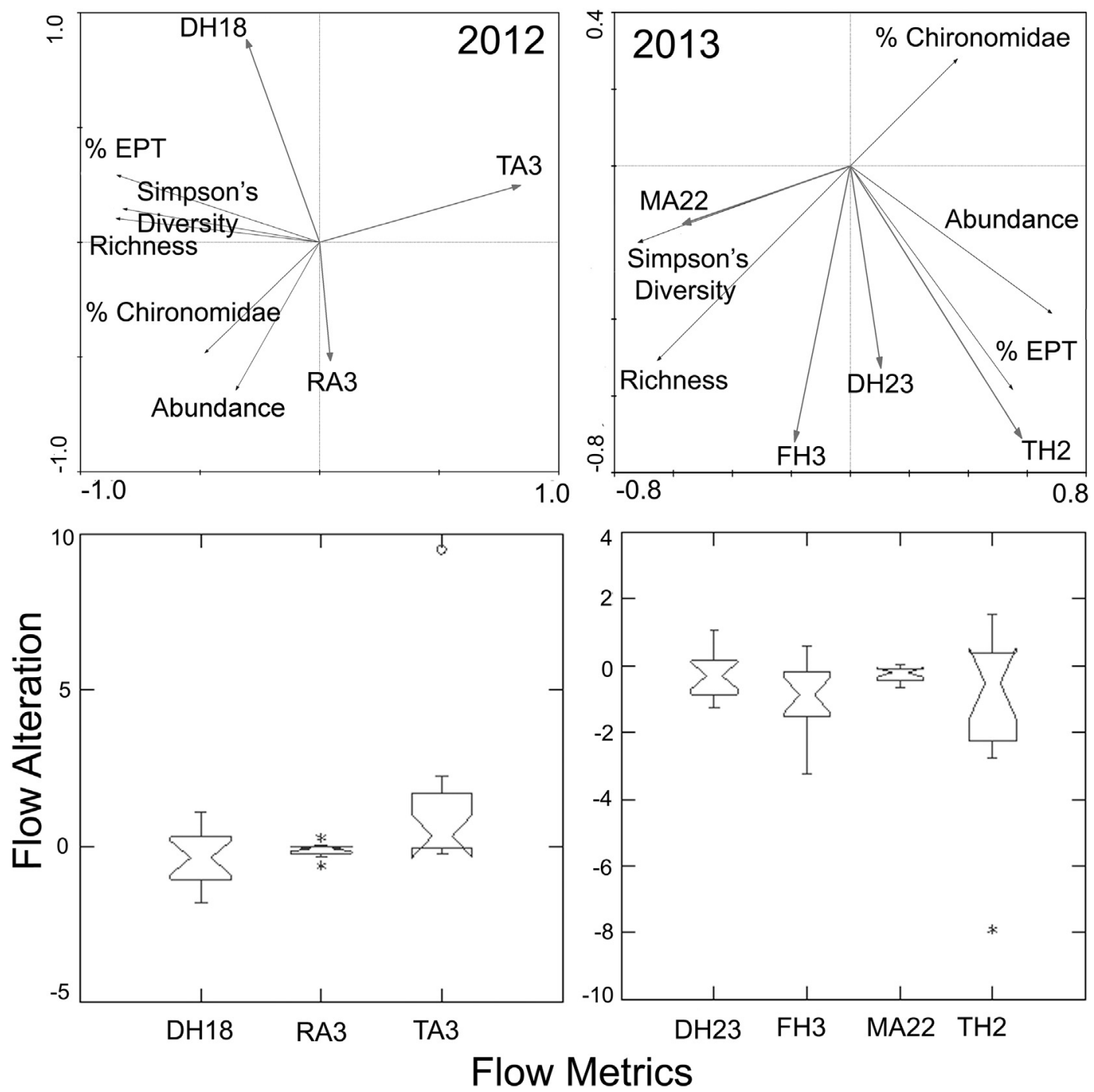

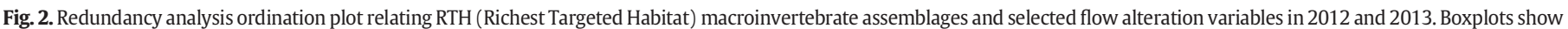

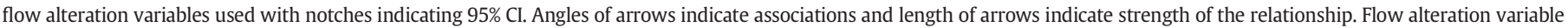
abbreviations and descriptions are given in Table 2.

positively related to alteration of RA3 (Fig. 2). Cumulative percent variance explained by flow alteration was $88.6 \%$ for Axes 1 and 2 (Table 3 ).

In 2013, RTH macroinvertebrate assemblages were significantly related to alteration of MA22, FH3, DH23, and TH2 (RDA $p<0.001$, Table 2, Fig. 2). MA22 and FH3 were significantly reduced relative to

Table 3

Cumulative \% variance in RDA axes.

\begin{tabular}{lcr}
\hline Assemblage & \multicolumn{2}{c}{ Cumulative \% variance explained } \\
\cline { 2 - 3 } & Axis 1 & Axis 2 \\
\hline 2012 (drought year) & & \\
RTH macroinvertebrates & 68.5 & 88.6 \\
QMH macroinvertebrates & 60.9 & 93.6 \\
Fish & 44.8 & 72.4 \\
Crayfish & 68.5 & 88.6 \\
2013 (flood year) & & \\
RTH macroinvertebrates & 54.9 & 80.2 \\
QMH macroinvertebrates & 43.4 & 69.6 \\
Fish & 54.0 & 86.7 \\
Crayfish & 57.7 & 90.7
\end{tabular}

expected values (Fig. 2). Diversity was positively related to alteration of MA22, while percent Chironomidae was negatively related to alteration of MA22 (Fig. 2). Percent EPT was positively related to alteration of TH2 (Fig. 2). Cumulative percent variance explained by flow alteration was $80.2 \%$ for Axes 1 and 2 (Table 3 ).

In RTH macroinvertebrate assemblages, no category of alteration metric stood out as most important. Of the seven important flow alteration metrics, two were duration, two were timing, one was magnitude, one was frequency, and one was rate of change (Table 2 , Fig. 2). Four of seven metrics were high flow metrics, and the remaining three were average flow metrics. No metrics belonging to the low flow category were important. No metrics were important in RTH macroinvertebrate assemblages in both years. One metric, DH23, was also an important metric in QMH macroinvertebrate assemblages, and two others, MA22 and RA3, were also important metrics in fish assemblages (Table 2).

\subsection{QMH macroinvertebrates}

In 2012, QMH macroinvertebrate response metrics were significantly related to alteration of MA12, MH3, MH20, ML12, and FH11 

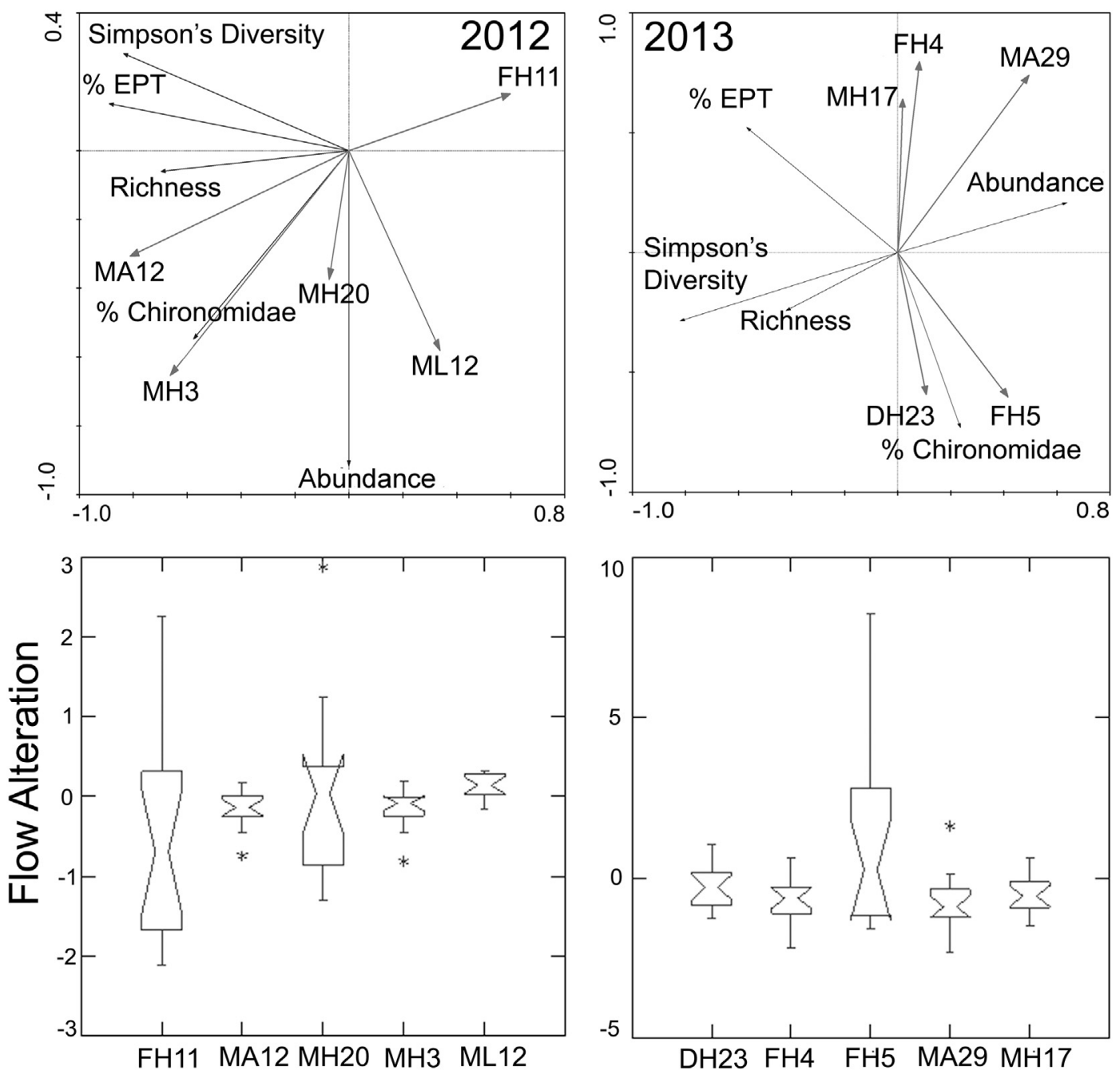

Flow Metrics

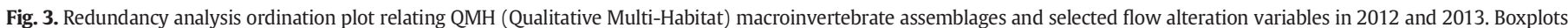

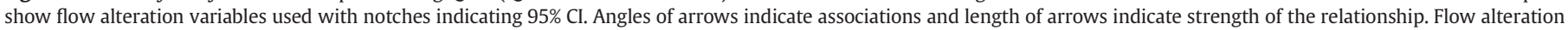
variable abbreviations and descriptions are given in Table 2 .

(RDA $p<0.001$, Table 2, Fig. 3). MA12 and MH3 were significantly reduced and ML12 significantly increased relative to expected values (Fig. 3). Richness, diversity, and percent EPT were all negatively related to alteration of FH11, while percent Chironomidae was positively related to alteration of MH3 (Fig. 3). Cumulative percent variance explained by flow alteration was 93.6\% for Axes 1 and 2 (Table 3).

In 2013, QMH macroinvertebrate response metrics were significantly related to alteration of MA29, MH17, FH4, FH5, and DH23 (RDA $p<0.001$, Table 2, Fig. 3), and MA29, MH17, and FH4 were significantly reduced relative to expected values (Fig. 3). Percent EPT was negatively related to alteration of FH5 and DH23, while alteration of both of these metrics was positively related to percent Chironomidae (Fig. 3). Cumulative percent variance explained by flow alteration was $69.6 \%$ for Axes 1 and 2 (Table 3 ).

In $\mathrm{QMH}$ macroinvertebrate assemblages, magnitude was the most important category of alteration metric; six of the ten important alteration metrics belonged to this category (Table 2, Fig. 3). Frequency was the second most important category, with three of the ten. One metric belonged to the duration category. Seven of the ten metrics were high flow metrics, with three average flow and one low flow. No metrics were important in QMH assemblages in both years. One metric, DH23, was also important in RTH macroinvertebrate assemblages, and another, FH11, in fish assemblages (Table 2).

\subsection{Crayfish}

In 2012, crayfish response metrics were significantly related to alteration of MA3, MA32, MA33, DL18 and RA2 (RDA $p<$ 0.001 , Table 2, Fig. 4). DL18, MA32, and MA33 were significantly reduced and RA2 significantly increased relative to expected values (Fig. 4). Diversity was negatively related to alteration of DL18, while total density and percent generalist crayfish were positively related to alteration of RA2 (Fig. 4). Cumulative percent variance explained by flow alteration was $88.6 \%$ for Axes 1 and 2 (Table 3 ).

In 2013, crayfish response metrics were significantly related to alteration of MA3, MA21, DH1, and TH1 (RDA $p<0.001$, Table 2, Fig. 4). DH1 was significantly reduced and TH1 significantly increased relative to expected values (Fig. 4). Total 

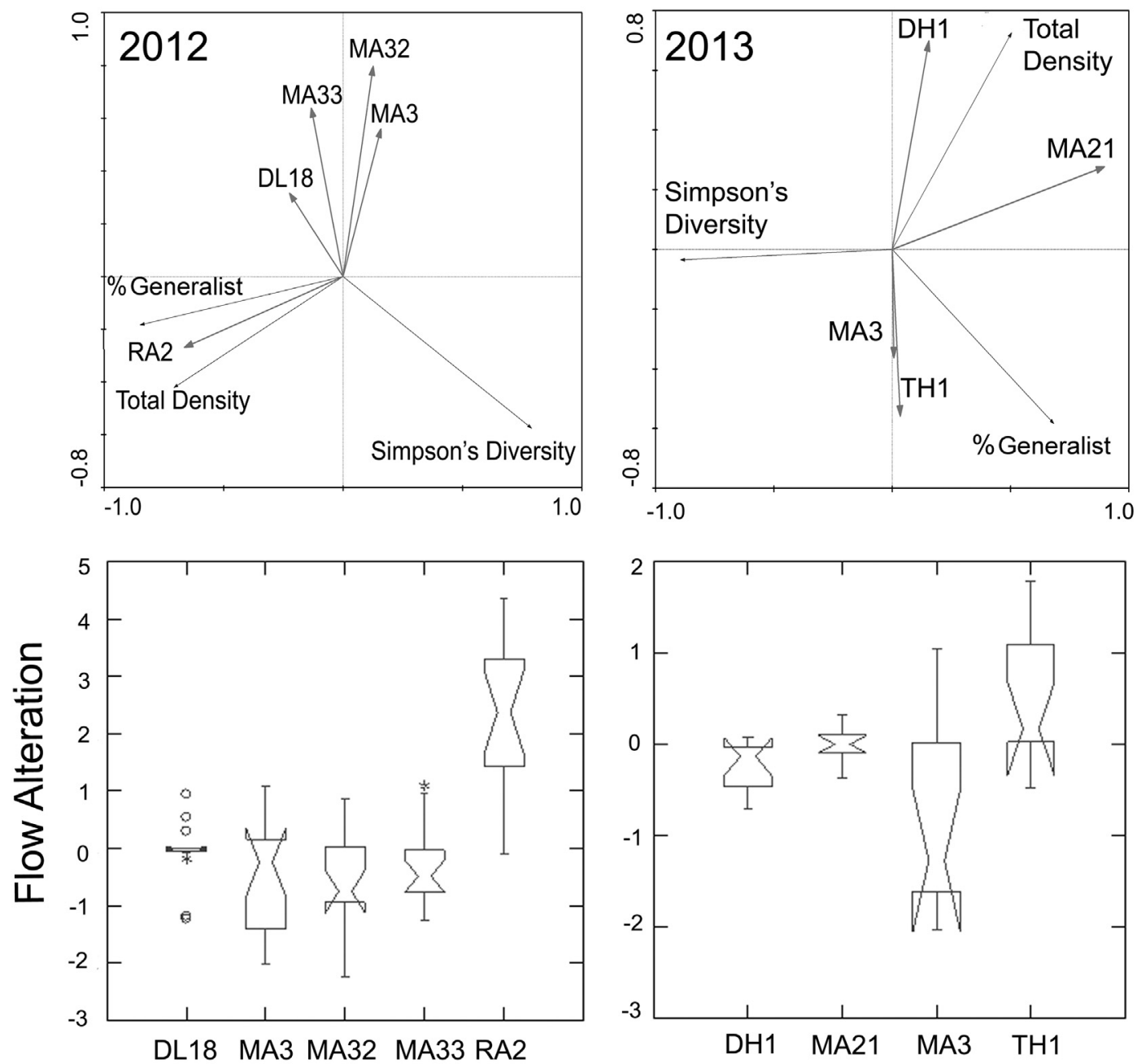

Flow Metrics

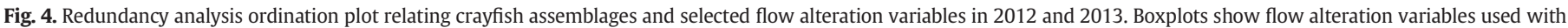

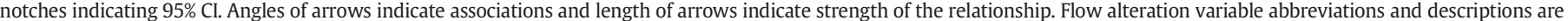
given in Table 2 .

Density was positively related to alteration of DH1 while diversity was negatively related to alteration of MA21 (Fig. 4). Cumulative percent variance explained by flow alteration was $90.7 \%$ for Axes 1 and 2 (Table 3 ).

In crayfish assemblages, magnitude was the most important category of alteration metric; five of the nine important alteration metrics between years belonged to this category (Table 2, Fig. 4). Of the remaining four important metrics, two belonged to the duration category, one to the timing category, and one to the rate of change category. Six of the nine metrics were average flow metrics, with two high flows, and one low flow. One metric, MA3, was an important metric in crayfish assemblages in both years. No specific metrics important to crayfish assemblages were important in other taxonomic groups (Table 2).

\subsection{Fish}

In 2012, fish response metrics were significantly related to alteration of MA22, MA36, FH1, FH2, FH8, and DH7 (RDA $p<0.001$, Table 2, Fig. 5). MA22, MA36, FH1, and FH2 were significantly reduced relative to expected values (Fig. 5). Diversity and richness were positively related to alteration of MA22, FH2, and MA36 and negatively related to alteration of DH7 (Fig. 4). Percent intolerant fish was negatively related to alteration of FH1 and FH8 (Fig. 5). Cumulative percent variance explained by flow alteration was $72.4 \%$ for Axes 1 and 2 (Table 3 ).

In 2013, fish response metrics were significantly related to alteration of MH13, MH18, FH11, DH7, and RA3 (RDA $p<0.001$, Table 2, Fig. 5). MH18 was significantly increased and RA3 significantly reduced relative to expected values (Fig. 5). Percent intolerant fish was positively related to alteration of MH18, total density negatively related to alteration of RA3, and richness and diversity negatively related to alteration of MH18 and DH7 (Fig. 5). Cumulative percent variance explained by flow alteration was $86.7 \%$ for Axes 1 and 2 (Table 3).

In fish assemblages, magnitude and frequency were the most important categories of flow alteration metrics; eight of the 11 important alteration metrics between years were in these two categories (Table 2 , Fig. 5). Of the remaining three important metrics, two belonged to the duration category and one to the rate of change category. Eight of the 11 metrics were high flow metrics and the remaining three were in the average flow category. No metrics belonging to the low flow category were important. No metrics were important in fish assemblages in both years. MA22 and RA3 were also important metrics in RTH macroinvertebrate assemblages and FH11 in QMH macroinvertebrate assemblages (Table 2). 

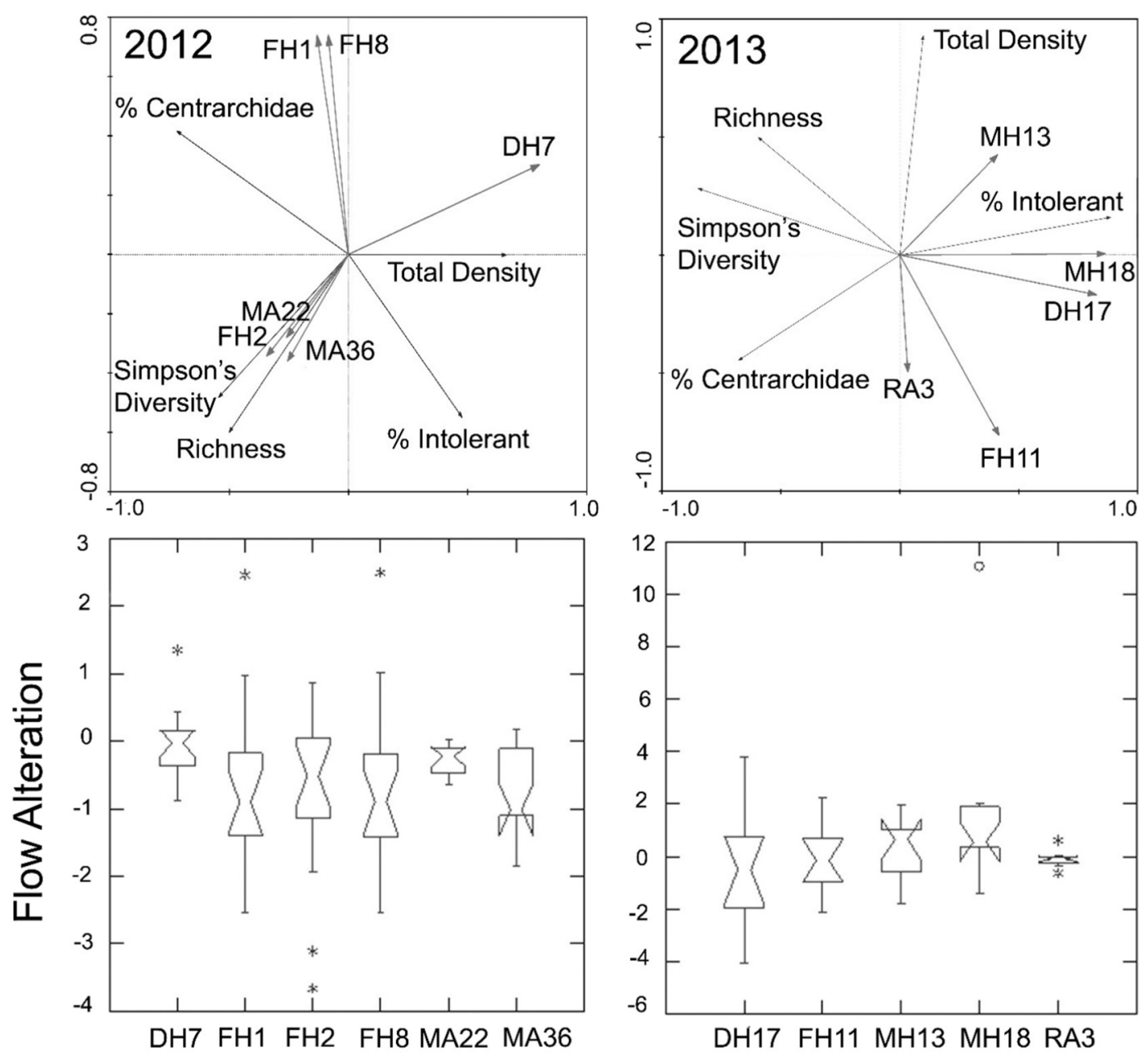

DH17 FH11 MH13 MH18 RA3

\section{Flow Metrics}

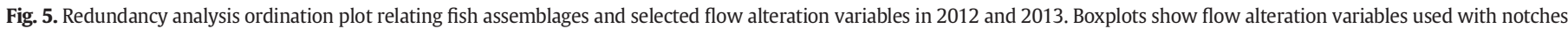

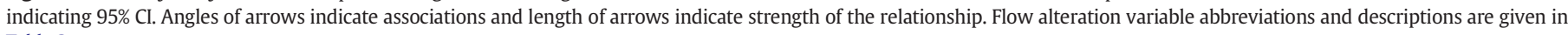
Table 2.

\subsection{Aquatic community}

Considering all four assemblages over both years, 32 different metrics of hydrologic alteration were significantly related to biological response metrics (Table 2). In order of importance, the five categories were ranked: magnitude (14), frequency (7), duration (6), timing (3) and rate of change (2). In terms of average, low, and high flows, metrics relating to alteration of high flows were the most numerous (19), followed by average flows (11), with a much lower number of important alteration metrics relating to low flows (2). All seven frequency metrics and all but one of the duration metrics were related to high flows, while the majority of important magnitude metrics were related to average flows. The four most important specific categories were MA (8), $\mathrm{FH}$ (7), $\mathrm{MH}$ (5), and DH (5). Four specific alteration metrics were important in multiple assemblages: MA22, FH11, DH23, and RA3 (Table 2).

\section{Discussion}

Our hypothesis that there would be temporal variation in flow alteration-ecology relationships was supported. The complete overlap of sites for macroinvertebrate collections makes it possible to draw temporal comparisons in flow alteration-ecological response relationships between the two years for macroinvertebrate assemblages. The contrast between years was most pronounced in the RTH samples, which may be because they are collected only from riffles, the stream habitat most heavily affected by drought (Dekar and Magoulick, 2007; Chester and Robson, 2011). While we expected some differences between the years, it was still somewhat surprising to see no consistently important metrics between the two years in either RTH or QMH collections. In some cases, there were seemingly different relationships between response metrics. For example, RTH percent EPT was negatively related to alteration of TA3 (seasonal predictability of flooding) in 2012, whereas percent EPT was positively related to alteration of TH2 (variability in Julian date of annual maximum) in 2013. However, in both cases percent EPT was reduced with altered flow timing (discussed further below). It appears that alteration of flow timing is important for percent EPT, but specific relationships vary temporally.

Non-stationarity in environmental conditions can complicate our ability to formulate predictable flow-ecology relationships and pose challenges for the implementation of e-flows science (Poff et al., 2010; Rolls et al., 2012; Katz and Freeman, 2015; Poff, 2017; Lynch et al., 
2018). As the hydrologic cycle is further altered by global climate change and the severity, duration and frequency of droughts increases (Masson-Delmotte et al., 2013; Farjad et al., 2015) it is crucial to incorporate strategies that realistically account for these phenomena when implementing e-flows science into management decisions (Poff, 2017). One such strategy is to focus on resilience, the maintenance of processes and relationships that are robust and able to maintain integrity despite anticipated changes in environmental conditions (Poff, 2017; Mazor et al., 2018).

Our hypotheses that flow alteration-ecology relationships would be stronger during the drought year and that fish assemblages would show the strongest flow-alteration relationships, had much less support, and showed year- and taxa-dependent caveats. Relationship strength, as indicated by cumulative percent variance explained in Axes 1 and 2 of the RDA's, was greater during the drought year for benthic macroinvertebrate assemblages, but weaker for fish and crayfish, with the pattern reversed during the flood year. Fish assemblage relationships were stronger than macroinvertebrates and lower than crayfish during the flood year, but weaker than all other groups during the drought year. Overall, relationships were slightly stronger during the drought year than the flood year, and relationships were actually weaker in fish than in the macroinvertebrate assemblages.

With respect to which categories of alteration metrics were most important, the prominence of magnitude and frequency is of particular interest given that regional e-flows studies have suggested that magnitude of flow is an important influence on aquatic communities (Monk et al., 2006; Armstrong et al., 2011; Kendy et al., 2012), while others have found that frequency of floods may be one of the most important determinants of community structure in streams (Dodds et al., 2004; Matthews et al., 2013; Matthews et al., 2014). Anthropogenic alteration of streamflow magnitudes is a widespread phenomenon; in an assessment of 2888 streamflow monitoring sites throughout the conterminous U.S., Carlisle et al. (2010) found that streamflow magnitude was altered at $86 \%$ of assessed streams, and that diminished magnitudes were better predictors of biological integrity in both fish and macroinvertebrate assemblages than other physical and chemical covariates. Reduction in high flow frequencies has also been linked to a decrease in the ecological integrity of river systems (Ward and Stanford, 1995). The general trend in our study area in both magnitude and frequency metrics was towards reduction relative to expected values.

Compared to alteration of high and average flows, alteration of low flows appeared to be a considerably less important influence on biota in Groundwater Flashy streams in the Ozark Highlands; only two of 32 important metrics across years and assemblages were low flow related. Although both floods and droughts act as major hydrologic disturbances in stream ecosystems and can exert significant influence on biota (Lake, 2000), the alteration of low-flow hydrology has been relatively less studied than that of high flows (Rolls et al., 2012). In the present study, we focused on Groundwater Flashy streams, one of the most common flow regimes in the Ozark Highlands (Leasure et al., 2016), but it is likely that in other flow regimes, alteration of low flows may be more important. Different natural flow regimes within the same region may be more or less susceptible to particular forms of flow alteration, which is the reason that flow regime classification is a crucial step in the assessment of hydrologic alteration (Poff et al., 2010). The seven distinct flow regimes in the Ozark Highlands can be divided into three broad categories - groundwater, runoff, and intermittent streams (Leasure et al., 2016). Runoff and intermittent flow regimes are categorized by more frequent low flow spells and lower base flows than groundwater streams; it may be that low flow metrics play a greater role in the life history of biota in these streams and therefore alteration of those metrics would have greater impact. Poff (1992) suggested that perennial runoff and intermittent streams may be more strongly affected by alteration of low flows and groundwater streams more affected by alteration of high flows; the latter at least appears to be reflected in the present study.

RTH macroinvertebrate assemblages differed in key ways from the others in this study. This was the only group in which magnitude was not the most important category of flow alteration metric. It was also the only assemblage in which no flow alteration category was clearly more prominent than the others. Predictability of flooding is thought to be critically important to macroinvertebrate assemblages. Fritz and Dodds (2005) found that streams with low flow predictability had consistently lower macroinvertebrate taxa richness than those with greater predictability. Alteration of the variability in high flow timing (TH2) was also related to both percent EPT taxa and abundance in 2013. Predictable timing of floods may be very important in aquatic macroinvertebrates that rely on life-history adaptations to avoid disturbances rather than escaping on a per-event basis, particularly taxa that require gill respiration as juveniles but have an aerial adult stage, e.g. EPT taxa (Lytle, 2008). In the present study, predictability of flooding (TA3) was altered towards higher predictability and was negatively related to all response variables in 2012. Likewise, alteration towards increased variability in high flow timing (TH2) was positively related to increased percent EPT taxa and abundance in 2013, but it is important to note that TH2 alteration ranges from strongly negative to slightly positive so percent EPT and abundance increased with less altered (i.e., more normal) TH2. Therefore, in both cases percent EPT was reduced with altered flow timing. It appears that alteration of flow timing, regardless of direction, may negatively influence RTH macroinvertebrate assemblages in these systems.

Unlike RTH assemblages, QMH assemblages showed a pattern consistent with fish and crayfish assemblages with respect to the prominence of magnitude alteration metrics. Interestingly, QMH assemblages show more of an affinity with fish than crayfish assemblages in terms of the importance of high flow frequency (FH). Relationships between response variables in the two years were more consistent in QMH than RTH samples. It is possible that the inclusion of pool and run habitats, which act as refuges for macroinvertebrates during summer drying (Chester and Robson, 2011), may have somewhat ameliorated the effects of drought in 2012 in QMH compared to RTH samples. Temporal variation in relationships was also apparent in QMH assemblages, however, as no individual flow alteration metrics were significant in both years. General trends among QMH macroinvertebrate assemblages in the region include reduction of important metrics relating to magnitude and variability in average and high flows, as well as frequency and duration of high flows. These may have a variety of effects on QMH macroinvertebrate assemblages in the region; in a few cases, some trends may actually offset each other. For example, decreasing magnitude of average flows (MA12) may lead to a decrease in richness which could be somewhat ameliorated by the trend towards decreasing flood frequency (FH11) (Fig. 3). Examining synergies and indirect effects of flow alteration on ecosystem structure and function could be a fruitful avenue for future research.

It should be noted that care should be taken in interpreting the flow alteration-ecology relationships because flow can be negatively or positively altered or unaltered. Therefore, negative alteration can be positively correlated with a response variable. For example, in Fig. 2 the alteration of FH3 is positively related to Taxa Richness and negatively related to \%Chironomidae, but FH3 is negatively altered and high FH3 values are near normal (i.e., FH3 $=0$ ). Therefore, Taxa Richness is greater and \%Chironomidae is reduced when FH3 is near normal. 
Magnitude alteration was the most important category in both crayfish and fish assemblages. The two strongly differ in one important way, however - the lack of any important frequency alteration metrics in crayfish assemblages. The ability of crayfish species in the region to more fully utilize the hyporheic zone during dry periods (DiStefano et al., 2009; Larson et al., 2009) may make them less dependent on frequent high flow events than fish assemblages; this may lessen the impact that alteration of flood frequency has on them. MA3, variability in daily flows, was a consistently important metric in crayfish assemblages in the region, as it was selected in both 2012 and 2013 despite a lack of overlap between sites. The relationship between alteration of flow variability and density was similar to that observed in fish assemblages in this study, i.e. the relationship between fish density and MA36 in 2012, and is also supported by previous studies of flow variability and fish density (Craven et al., 2010).

In fish assemblages, the association between richness and diversity and alteration of variability in both average flow magnitude (MA22 and MA36) and high flow frequency, (FH2) is supported by studies relating hydrologic variation to North American stream fishes (Ward, 1998; Niu et al., 2012, but see McGarvey, 2014). The trend towards reduction of these metrics in our study area could be associated with an overall decline in richness and diversity of stream fishes in the region. While previous studies have suggested that aquatic biodiversity is often lower in modified or disturbed streams than in those with relatively intact natural flow regimes (Ward and Stanford, 1995; Gehrke et al., 1999), it has been an ongoing challenge for stream ecologists to unravel the direct effects of flow alteration from multiple associated stressors that often accompany development in watersheds, e.g. land-use factors or declining water quality (Bunn and Arthington, 2002). Our study provides evidence that alteration of specific flow metrics can influence richness and diversity in stream biota.

Overall, our results show the importance of magnitude and high flow alteration to stream assemblages in these systems. However, patterns related to alteration of specific flow metrics between years or between taxa are less obvious. It is possible that redundancy between tested flow metrics used to explain similar ecological processes may be responsible for lack of patterns with specific flow metrics. Future research that builds on established flow alteration-biological response relationships in a way that specifically elucidates functional links would be worthwhile.

Another caveat to consider is that, while relationships appeared to vary between years, our ability to detect these relationships may have varied as well based on the very different sampling conditions between drought and flood years. Detection probability of freshwater fish can vary strongly between samples taken at different flow magnitudes, and this may influence inferences based on fish community-flow relationships (Pregler et al., 2015; Gwinn et al., 2016). Similar factors may affect detection probability in benthic macroinvertebrate assemblages (Meador et al., 2011; Wisniewski et al., 2013). Furthermore, while hydrology plays a major role in structuring aquatic assemblages, it is heavily interrelated to many other factors, including geomorphology, land-use, and water quality; the ecological effects of hydrologic alteration are best examined within the context of this suite of factors (Poff et al., 2006; McManamay and Frimpong, 2015; Lynch et al., 2018). Finally, while we examined flow alteration-ecology relationships in a predominant flow regime (Groundwater Flashy streams) in the Ozark Highlands, these relationships may strongly differ in other flow regimes even within the same ecoregion (Poff, 1992; Poff et al., 2010; Leasure et al., 2016). Future studies of flow alteration-ecology relationships focused on other flow regimes would help to form a more complete picture of the impact of hydrologic alteration on stream communities.

\section{Conclusions}

Flow alteration appears to be an important influence on community structure in Groundwater Flashy streams in the Ozark Highlands. The most important categories of alteration influencing stream biota were $\mathrm{MA}, \mathrm{FH}, \mathrm{MH}$, and $\mathrm{DH}$. The fact that three of these categories were high flow-related suggests the overall importance of high flows as a determinant of community structure and composition in these systems. Of the 32 important metrics across years and assemblages, 19 were significantly altered relative to expected values. General patterns, such as the importance of magnitude and high flow alteration, were apparent across assemblages and may be useful to managers and stakeholders attempting to conserve freshwater ecosystems in the region. However, key differences between taxonomic groups, as well as temporal variation in relationships, suggest that a complex suite of flow metrics should be considered for effective conservation of stream communities related to flow alteration. Environmental flows concepts are increasingly finding traction in regions across the world (Belmar et al., 2011; Buchanan et al., 2013; Rolls and Arthington, 2014; O'Brien et al., 2017; Zhang et al., 2012), but could be enhanced by a better understanding of complexity with respect to interactions between temporal variation, disturbance, and taxa-dependent response differences.

\section{Acknowledgements}

We thank the Arkansas Game and Fish Commission and State Wildlife Grants for funding. We thank our project partners: Dr. John Jackson, Jim Petersen, Jeff Quinn, and Ethan Inlander. We thank Brian Haggard and the staff of the Arkansas Water Resources Water Quality Lab and Eric Cummings and the University of Arkansas Ecological Engineering Group. We thank Brad Austin and Scott Longing for assistance with laboratory methods and Chris Middaugh for GIS assistance. Finally we thank the many people who have assisted us with data collection in the field and laboratory: Joseph Baecher, Alexa Ballinger, Brooke Beckwith, Tom Boersig, Lindsey Bruckerhoff, Kelsey Deal, Alan Edmundson, Matt Gideon, Alexandra Hooks, Alexa Kusmik, Philip Malone, Brianna Olsen, Kayla Sayre, Jared Schluterman, Keith Waters, Kaitlyn Werner, Shannon Wiley, and Tyler Williams. This study was done under the auspices of University of Arkansas IACUC protocol \#11018. The authors have no conflicts of interest related to this research. Any use of trade, firm, or product names is for descriptive purposes only and does not imply endorsement by the U.S. Government.

\section{Appendix A}

\begin{tabular}{ll}
\hline Predictor variable & Spatial extent \\
\hline Average base flow index & $\mathrm{W}, \mathrm{P}$ \\
Average groundwater recharge & $\mathrm{W}, \mathrm{P}$ \\
Maximum elevation & $\mathrm{W}$ \\
Maximum slope & $\mathrm{W}$ \\
Watershed ratio & $\mathrm{W}$ \\
Watershed area & $\mathrm{W}$ \\
Average stream slope & $\mathrm{W}, \mathrm{P}$ \\
Density of upstream confluences & $\mathrm{W}$ \\
Count of upstream confluences & $\mathrm{W}$ \\
Spring density & $\mathrm{W}$ \\
Spring count & $\mathrm{W}$ \\
Percent coverage of shale & $\mathrm{W}$ \\
Percent coverage of dolostone & $\mathrm{W}$ \\
Coverage of shale & $\mathrm{W}$ \\
Coverage of dolostone & $\mathrm{W}$ \\
Percent coverage of Ozark Plateau aquifer & $\mathrm{W}$
\end{tabular}


(continued)

\begin{tabular}{|c|c|}
\hline Predictor variable & Spatial extent \\
\hline Coverage of Ozark Plateau aquifer & W \\
\hline Average bulk density & $\mathrm{W}, \mathrm{P}$ \\
\hline Average soil clay content & $\mathrm{W}, \mathrm{P}$ \\
\hline Subsurface flow contact time index & $\mathrm{W}, \mathrm{P}$ \\
\hline Average soil water capacity & $\mathrm{W}, \mathrm{P}$ \\
\hline Average water table depth & $\mathrm{W}, \mathrm{P}$ \\
\hline Average hydrologic group B & $\mathrm{W}, \mathrm{P}$ \\
\hline Average hydrologic group C & $\mathrm{W}, \mathrm{P}$ \\
\hline Average hydrologic group D & $\mathrm{W}, \mathrm{P}$ \\
\hline Infiltration-excess overland flow rates & $\mathrm{W}, \mathrm{P}$ \\
\hline Average soil $\mathrm{K}$ factor & $\mathrm{W}, \mathrm{P}$ \\
\hline Average soil organic matter & $\mathrm{W}, \mathrm{P}$ \\
\hline Average overland flow & $\mathrm{W}, \mathrm{P}$ \\
\hline Snow percent of total precipitation & $\mathrm{W}, \mathrm{P}$ \\
\hline Average soil fraction $<0.74 \mathrm{~mm}$ & $\mathrm{~W}, \mathrm{P}$ \\
\hline Average soil fraction $<2 \mathrm{~mm}$ & $\mathrm{~W}, \mathrm{P}$ \\
\hline Average soil fraction $<5 \mathrm{~mm}$ & $\mathrm{~W}, \mathrm{P}$ \\
\hline Average soil permeability & $\mathrm{W}, \mathrm{P}$ \\
\hline Average annual potential evapotranspiration & $\mathrm{W}, \mathrm{P}$ \\
\hline Average rainfall and runoff factor & $\mathrm{W}, \mathrm{P}$ \\
\hline Average rock depth & $\mathrm{W}, \mathrm{P}$ \\
\hline Average percent sand & $\mathrm{W}, \mathrm{P}$ \\
\hline Average percent silt & $\mathrm{W}, \mathrm{P}$ \\
\hline Dominant surface geology & $\mathrm{W}, \mathrm{P}$ \\
\hline Average topographic wetness index & $\mathrm{W}, \mathrm{P}$ \\
\hline Percent coverage of limestone & W \\
\hline Percent coverage of sand & W \\
\hline Percent coverage of sandstone & W \\
\hline Coverage of limestone & W \\
\hline Coverage of sand & $\mathrm{W}$ \\
\hline Coverage of sandstone & W \\
\hline Canopy cover & W \\
\hline Average elevation & $\mathrm{W}, \mathrm{P}$ \\
\hline Elevation range & W \\
\hline Average slope & $\mathrm{W}, \mathrm{P}$ \\
\hline Isothermality & W, P \\
\hline Maximum temperature of warmest month & $\mathrm{W}, \mathrm{P}$ \\
\hline Average diurnal temperature range & $\mathrm{W}, \mathrm{P}$ \\
\hline Average temperature coldest quarter & W, P \\
\hline Average temperature driest quarter & $\mathrm{W}, \mathrm{P}$ \\
\hline Average temperature warmest quarter & $\mathrm{W}, \mathrm{P}$ \\
\hline Average temperature wettest quarter & $\mathrm{W}, \mathrm{P}$ \\
\hline Minimum temperature coldest month & $\mathrm{W}, \mathrm{P}$ \\
\hline Precipitation coldest quarter & $\mathrm{W}, \mathrm{P}$ \\
\hline Precipitation driest month & $\mathrm{W}, \mathrm{P}$ \\
\hline Precipitation driest quarter & $\mathrm{W}, \mathrm{P}$ \\
\hline Precipitation January & $\mathrm{W}, \mathrm{P}$ \\
\hline Precipitation February & $\mathrm{W}, \mathrm{P}$ \\
\hline Precipitation March & W, P \\
\hline Precipitation April & $\mathrm{W}, \mathrm{P}$ \\
\hline Precipitation May & $\mathrm{W}, \mathrm{P}$ \\
\hline Precipitation June & $\mathrm{W}, \mathrm{P}$ \\
\hline Precipitation July & $\mathrm{W}, \mathrm{P}$ \\
\hline Precipitation August & $\mathrm{W}, \mathrm{P}$ \\
\hline Precipitation September & $\mathrm{W}, \mathrm{P}$ \\
\hline Precipitation October & $\mathrm{W}, \mathrm{P}$ \\
\hline Precipitation November & $\mathrm{W}, \mathrm{P}$ \\
\hline Precipitation December & $\mathrm{W}, \mathrm{P}$ \\
\hline Precipitation seasonality & $\mathrm{W}, \mathrm{P}$ \\
\hline Precipitation warmest quarter & $\mathrm{W}, \mathrm{P}$ \\
\hline Precipitation wettest month & $\mathrm{W}, \mathrm{P}$ \\
\hline Precipitation wettest quarter & $\mathrm{W}, \mathrm{P}$ \\
\hline Temperature annual range & $\mathrm{W}, \mathrm{P}$ \\
\hline Temperature seasonality & $\mathrm{W}, \mathrm{P}$ \\
\hline Average temperature January & $\mathrm{W}, \mathrm{P}$ \\
\hline Average temperature February & $\mathrm{W}, \mathrm{P}$ \\
\hline Average temperature March & $\mathrm{W}, \mathrm{P}$ \\
\hline Average temperature April & $\mathrm{W}, \mathrm{P}$ \\
\hline Average temperature May & $\mathrm{W}, \mathrm{P}$ \\
\hline Average temperature June & $\mathrm{W}, \mathrm{P}$ \\
\hline Average temperature July & W, P \\
\hline Average temperature August & $\mathrm{W}, \mathrm{P}$ \\
\hline Average temperature September & $\mathrm{W}, \mathrm{P}$ \\
\hline Average temperature October & $\mathrm{W}, \mathrm{P}$ \\
\hline Average temperature November & $\mathrm{W}, \mathrm{P}$ \\
\hline Average temperature December & $\mathrm{W}, \mathrm{P}$ \\
\hline
\end{tabular}

(continued)

\begin{tabular}{|c|c|}
\hline Predictor variable & Spatial extent \\
\hline Percent coverage of chert & W \\
\hline Percent coverage of alluvial terrace & W \\
\hline Percent coverage of alluvium & W \\
\hline Coverage of chert & W \\
\hline Coverage of alluvial terrace & W \\
\hline Coverage of alluvium & W \\
\hline Dominant geology & $\mathrm{W}, \mathrm{P}$ \\
\hline Coverage of forest in 1992 & W \\
\hline Coverage of wetlands in 1992 & W \\
\hline Percent coverage of forest in 1992 & W \\
\hline Percent coverage of wetlands in 1992 & W \\
\hline Percent coverage of deciduous forests in 1992 & W \\
\hline Percent coverage of evergreen forests in 1992 & W \\
\hline Percent coverage of mixed forests in 1992 & W \\
\hline Coverage of deciduous forests in 1992 & W \\
\hline Coverage of evergreen forests in 1992 & W \\
\hline Coverage of mixed forests in 1992 & W \\
\hline Dominant aspect & $\mathrm{W}, \mathrm{P}$ \\
\hline Average annual temperature & $\mathrm{W}, \mathrm{P}$ \\
\hline Annual precipitation & $\mathrm{W}, \mathrm{P}$ \\
\hline Maximum temperature January & $\mathrm{W}, \mathrm{P}$ \\
\hline Maximum temperature February & $\mathrm{W}, \mathrm{P}$ \\
\hline Maximum temperature March & $\mathrm{W}, \mathrm{P}$ \\
\hline Maximum temperature April & $\mathrm{W}, \mathrm{P}$ \\
\hline Maximum temperature May & W, P \\
\hline Maximum temperature June & $\mathrm{W}, \mathrm{P}$ \\
\hline Maximum temperature July & $\mathrm{W}, \mathrm{P}$ \\
\hline Maximum temperature August & $\mathrm{W}, \mathrm{P}$ \\
\hline Maximum temperature September & $\mathrm{W}, \mathrm{P}$ \\
\hline Maximum temperature October & $\mathrm{W}, \mathrm{P}$ \\
\hline Maximum temperature November & $\mathrm{W}, \mathrm{P}$ \\
\hline Maximum temperature December & $\mathrm{W}, \mathrm{P}$ \\
\hline Minimum temperature January & $\mathrm{W}, \mathrm{P}$ \\
\hline Minimum temperature February & $\mathrm{W}, \mathrm{P}$ \\
\hline Minimum temperature March & $\mathrm{W}, \mathrm{P}$ \\
\hline Minimum temperature April & $\mathrm{W}, \mathrm{P}$ \\
\hline Minimum temperature May & $\mathrm{W}, \mathrm{P}$ \\
\hline Minimum temperature June & $\mathrm{W}, \mathrm{P}$ \\
\hline Minimum temperature July & $\mathrm{W}, \mathrm{P}$ \\
\hline Minimum temperature August & $\mathrm{W}, \mathrm{P}$ \\
\hline Minimum temperature September & $\mathrm{W}, \mathrm{P}$ \\
\hline Minimum temperature October & $\mathrm{W}, \mathrm{P}$ \\
\hline Minimum temperature November & $\mathrm{W}, \mathrm{P}$ \\
\hline Minimum temperature December & $\mathrm{W}, \mathrm{P}$ \\
\hline Minimum winter temperature & $\mathrm{W}, \mathrm{P}$ \\
\hline Dominant aquifer & $\mathrm{W}, \mathrm{P}$ \\
\hline Average annual runoff & $\mathrm{W}, \mathrm{P}$ \\
\hline Average runoff January & $\mathrm{W}, \mathrm{P}$ \\
\hline Average runoff February & $\mathrm{W}, \mathrm{P}$ \\
\hline Average runoff March & $\mathrm{W}, \mathrm{P}$ \\
\hline Average runoff April & $\mathrm{W}, \mathrm{P}$ \\
\hline Average runoff May & $\mathrm{W}, \mathrm{P}$ \\
\hline Average runoff June & $\mathrm{W}, \mathrm{P}$ \\
\hline Average runoff July & $\mathrm{W}, \mathrm{P}$ \\
\hline Average runoff August & $\mathrm{W}, \mathrm{P}$ \\
\hline Average runoff September & W, P \\
\hline Average runoff October & $\mathrm{W}, \mathrm{P}$ \\
\hline Average runoff November & $\mathrm{W}, \mathrm{P}$ \\
\hline Average runoff December & $\mathrm{W}, \mathrm{P}$ \\
\hline Coverage of red clay & W \\
\hline Coverage of cherty red clay & W \\
\hline Coverage of loam & W \\
\hline Coverage of sandy and stony colluvium & W \\
\hline Coverage of floodplain and alluvium gravel terraces & W \\
\hline Percent coverage of red clay & W \\
\hline Percent coverage of cherty red clay & W \\
\hline Percent coverage of loam & W \\
\hline Percent coverage of sandy and stony colluvium & W \\
\hline Percent coverage of floodplain and alluvium gravel terraces & W \\
\hline Percent coverage of Edwards-Trinity aquifer & W \\
\hline Coverage of Edwards-Trinity aquifer & W \\
\hline Stream density & W \\
\hline Stream length & W \\
\hline Minimum elevation & W \\
\hline Maximum stream slope & W \\
\hline Strahler stream order & $P$ \\
\hline Shreve stream order & $\mathrm{P}$ \\
\hline
\end{tabular}




\begin{tabular}{|c|c|c|c|c|c|c|c|c|c|c|c|c|c|c|}
\hline $\begin{array}{l}\text { Flow } \\
\text { metric }\end{array}$ & Definition & $n$ & Unique & Shift & Bias & $\begin{array}{l}\text { Bias } \\
\text { (interquartile } \\
\text { range) }\end{array}$ & Imprecision & $\begin{array}{l}\text { Imprecision } \\
\text { (interquartile } \\
\text { range) }\end{array}$ & $\begin{array}{l}\text { Absolute } \\
\text { error }\end{array}$ & $\begin{array}{l}\text { Absolute } \\
\text { Error } \\
\text { (interquartile } \\
\text { range) }\end{array}$ & $\mathrm{R}^{2}$ & $\begin{array}{l}\mathrm{R}^{2} \\
\text { (interquartile } \\
\text { range) }\end{array}$ & $\begin{array}{l}\text { Root } \\
\text { mean } \\
\text { square } \\
\text { error }\end{array}$ & $\begin{array}{l}\text { Normalized } \\
\text { root mean } \\
\text { square error }\end{array}$ \\
\hline MA1 & Mean daily flow & 64 & 64 & 1 & -0.07 & -0.04 & 0.37 & 0.23 & 0.23 & 0.15 & 0.89 & 0.85 & 0.49 & 0.07 \\
\hline MA2 & Median daily flow & 64 & 57 & 1 & -0.01 & 0.00 & 0.67 & 0.37 & 0.34 & 0.19 & 0.89 & 0.81 & 0.54 & 0.08 \\
\hline MA3 & Coefficient of variation in daily flows & 64 & 64 & 0 & -5.47 & -0.09 & 48.49 & 0.76 & 24.53 & 0.38 & 0.73 & 0.62 & 36.57 & 0.11 \\
\hline MA4 & Coefficient of variation of the logs in daily flows corresponding to the & 64 & 64 & 1 & -0.02 & -0.09 & 0.17 & 0.64 & 0.09 & 0.32 & 0.76 & 0.68 & 0.14 & 0.12 \\
\hline MA5 & Mean daily flows divided by median daily flows & 64 & 60 & 0 & 0.22 & 0.12 & 1.17 & 0.64 & 0.64 & 0.35 & 0.50 & 0.65 & 1.43 & 0.11 \\
\hline MA6 & Ratio of 10 th/90th percentiles in daily flows overall years & 55 & 55 & 1 & 0.13 & 0.04 & 0.75 & 0.24 & 0.42 & 0.13 & 0.73 & 0.87 & 0.93 & 0.13 \\
\hline MA7 & Ratio of 20th/80th percentiles in daily flows overall years & 61 & 60 & 1 & 0.07 & 0.04 & 0.69 & 0.35 & 0.35 & 0.18 & 0.68 & 0.82 & 0.68 & 0.12 \\
\hline MA8 & Ratio of 25 th/75th percentiles in daily flows overall years & 64 & 63 & 1 & 0.06 & 0.04 & 0.45 & 0.32 & 0.22 & 0.16 & 0.65 & 0.84 & 0.54 & 0.13 \\
\hline MA9 & Ranges in daily flows (MA6) divided by median daily flows & 64 & 60 & 0 & 0.43 & 0.10 & 2.33 & 0.53 & 1.13 & 0.26 & 0.45 & 0.74 & 3.87 & 0.10 \\
\hline MA10 & Ranges in daily flows (MA7) divided by median daily flows & 64 & 61 & 0 & 0.18 & 0.09 & 1.06 & 0.53 & 0.57 & 0.29 & 0.49 & 0.71 & 1.49 & 0.10 \\
\hline MA11 & Ranges in daily flows (MA8) divided by median daily flows & 64 & 59 & 0 & 0.10 & 0.07 & 0.76 & 0.53 & 0.40 & 0.28 & 0.52 & 0.72 & 0.93 & 0.11 \\
\hline MA12 & Mean monthly flow for January & 64 & 64 & 1 & -0.10 & -0.07 & 0.51 & 0.34 & 0.26 & 0.17 & 0.85 & 0.83 & 0.57 & 0.08 \\
\hline MA13 & Mean monthly flow for February & 64 & 64 & 1 & -0.09 & -0.06 & 0.48 & 0.31 & 0.25 & 0.16 & 0.87 & 0.84 & 0.54 & 0.08 \\
\hline MA14 & Mean monthly flow for March & 64 & 64 & 0 & 47.42 & 0.07 & 262.62 & 0.38 & 122.23 & 0.18 & 0.73 & 0.82 & 455.00 & 0.10 \\
\hline MA15 & Mean monthly flow for April & 64 & 64 & 1 & -0.08 & -0.05 & 0.38 & 0.25 & 0.21 & 0.14 & 0.90 & 0.86 & 0.47 & 0.07 \\
\hline MA16 & Mean monthly flow for May & 64 & 64 & 1 & -0.12 & -0.08 & 0.42 & 0.26 & 0.23 & 0.14 & 0.90 & 0.86 & 0.48 & 0.07 \\
\hline MA17 & Mean monthly flow for June & 64 & 64 & 0 & 30.07 & 0.09 & 86.92 & 0.25 & 60.73 & 0.17 & 0.78 & 0.83 & 304.41 & 0.08 \\
\hline MA18 & Mean monthly flow for July & 64 & 64 & 1 & -0.07 & -0.03 & 0.66 & 0.34 & 0.34 & 0.17 & 0.88 & 0.83 & 0.54 & 0.08 \\
\hline MA19 & Mean monthly flow for August & 64 & 64 & 1 & 0.01 & 0.01 & 0.61 & 0.33 & 0.29 & 0.16 & 0.90 & 0.84 & 0.53 & 0.07 \\
\hline MA20 & Mean monthly flow for September & 64 & 64 & 1 & -0.03 & -0.02 & 0.44 & 0.27 & 0.25 & 0.15 & 0.86 & 0.85 & 0.54 & 0.08 \\
\hline MA21 & Mean monthly flow for October & 64 & 64 & 1 & -0.08 & -0.05 & 0.45 & 0.27 & 0.26 & 0.15 & 0.84 & 0.85 & 0.60 & 0.09 \\
\hline MA22 & Mean monthly flow for November & 64 & 64 & 1 & -0.06 & -0.04 & 0.71 & 0.45 & 0.36 & 0.22 & 0.84 & 0.78 & 0.59 & 0.09 \\
\hline MA23 & Mean monthly flow for December & 64 & 64 & 1 & -0.05 & -0.03 & 0.63 & 0.41 & 0.33 & 0.22 & 0.84 & 0.78 & 0.59 & 0.09 \\
\hline MA24 & Coefficient of variation in monthly flows for January & 64 & 46 & 0 & -0.08 & 0.00 & 24.64 & 0.52 & 12.17 & 0.26 & 0.67 & 0.74 & 20.39 & 0.14 \\
\hline MA25 & Coefficient of variation in monthly flows for February & 64 & 47 & 0 & 0.45 & 0.01 & 20.26 & 0.60 & 10.52 & 0.31 & 0.65 & 0.69 & 16.74 & 0.12 \\
\hline MA26 & Coefficient of variation in monthly flows for March & 64 & 46 & 0 & 1.25 & 0.03 & 20.67 & 0.54 & 10.69 & 0.28 & 0.68 & 0.72 & 16.32 & 0.14 \\
\hline MA27 & Coefficient of variation in monthly flows for April & 64 & 47 & 0 & 0.03 & 0.00 & 23.84 & 0.65 & 12.05 & 0.33 & 0.71 & 0.67 & 16.69 & 0.13 \\
\hline MA28 & Coefficient of variation in monthly flows for May & 64 & 53 & 0 & 1.73 & 0.04 & 23.53 & 0.49 & 11.75 & 0.24 & 0.75 & 0.76 & 19.58 & 0.12 \\
\hline MA29 & Coefficient of variation in monthly flows for June & 64 & 59 & 0 & 3.94 & 0.06 & 21.74 & 0.34 & 11.85 & 0.18 & 0.80 & 0.82 & 19.00 & 0.12 \\
\hline MA30 & Coefficient of variation in monthly flows for July & 64 & 54 & 0 & 5.23 & 0.07 & 26.17 & 0.34 & 17.29 & 0.22 & 0.72 & 0.78 & 33.25 & 0.11 \\
\hline MA31 & Coefficient of variation in monthly flows for August & 64 & 58 & 0 & 6.74 & 0.08 & 37.92 & 0.46 & 21.78 & 0.27 & 0.65 & 0.73 & 41.52 & 0.12 \\
\hline MA32 & Coefficient of variation in monthly flows for September & 64 & 55 & 0 & 4.98 & 0.05 & 36.49 & 0.40 & 19.53 & 0.21 & 0.69 & 0.79 & 37.43 & 0.13 \\
\hline MA33 & Coefficient of variation in monthly flows for October & 64 & 54 & 1 & -0.03 & -0.03 & 0.34 & 0.35 & 0.18 & 0.18 & 0.79 & 0.82 & 0.33 & 0.12 \\
\hline MA34 & Coefficient of variation in monthly flows for November & 64 & 49 & 1 & -0.02 & -0.03 & 0.21 & 0.36 & 0.11 & 0.18 & 0.81 & 0.82 & 0.20 & 0.10 \\
\hline MA35 & Coefficient of variation in monthly flows for December & 64 & 53 & 0 & -0.78 & -0.01 & 20.40 & 0.32 & 9.85 & 0.16 & 0.74 & 0.84 & 20.59 & 0.11 \\
\hline MA36 & $\begin{array}{l}\text { Variability in monthly flows divided by median monthly flows, where variability is } \\
\text { calculated as range }\end{array}$ & 64 & 63 & 0 & 1.01 & 0.14 & 4.15 & 0.57 & 2.31 & 0.32 & 0.55 & 0.68 & 5.20 & 0.11 \\
\hline MA37 & $\begin{array}{l}\text { Variability in monthly flows divided by median monthly flows, where variability is } \\
\text { calculated as interquartile }\end{array}$ & 64 & 56 & 0 & 0.03 & 0.04 & 0.62 & 0.71 & 0.30 & 0.34 & 0.51 & 0.66 & 0.68 & 0.10 \\
\hline MA38 & $\begin{array}{l}\text { Variability in monthly flows divided by median monthly flows, where variability is } \\
\text { calculated as 90th-10th percentile }\end{array}$ & 64 & 61 & 1 & -0.04 & -0.12 & 0.23 & 0.67 & 0.10 & 0.29 & 0.63 & 0.71 & 0.19 & 0.11 \\
\hline MA39 & Coefficient of variation in mean monthly flows & 64 & 63 & 0 & 0.18 & 0.01 & 16.61 & 0.81 & 7.64 & 0.37 & 0.62 & 0.63 & 12.54 & 0.13 \\
\hline MA40 & (Mean monthly flow-median monthly flow)/median monthly flow & 64 & 51 & 1 & -0.01 & -0.02 & 0.16 & 0.64 & 0.08 & 0.34 & 0.55 & 0.66 & 0.16 & 0.11 \\
\hline MA41 & Mean annual flow divided by catchment area & 64 & 53 & 1 & 0.00 & -0.01 & 0.07 & 0.33 & 0.04 & 0.19 & 0.71 & 0.81 & 0.09 & 0.10 \\
\hline MA42 & $\begin{array}{l}\text { Variability in annual flows divided by median annual flows, where variability is } \\
\text { calculated as range }\end{array}$ & 64 & 46 & 0 & -0.05 & -0.09 & 0.51 & 1.00 & 0.25 & 0.49 & 0.38 & 0.51 & 0.35 & 0.15 \\
\hline MA43 & $\begin{array}{l}\text { Variability in annual flows divided by median annual flows, where variability is } \\
\text { calculated as interquartile }\end{array}$ & 64 & 38 & 1 & 0.00 & -0.04 & 0.10 & 0.93 & 0.05 & 0.48 & 0.35 & 0.52 & 0.09 & 0.18 \\
\hline MA44 & $\begin{array}{l}\text { Variability in annual flows divided by median annual flows, where variability is } \\
\text { calculated as 90th-10th percentile }\end{array}$ & 64 & 45 & 1 & 0.00 & 0.01 & 0.12 & 0.84 & 0.06 & 0.43 & 0.45 & 0.57 & 0.10 & 0.15 \\
\hline MA45 & (Mean annual flow-median annual flow)/median annual flow & 64 & 21 & 0 & 0.00 & 0.05 & 0.06 & 1.14 & 0.03 & 0.59 & 0.23 & 0.41 & 0.06 & 0.15 \\
\hline ML1 & Mean minimum monthly flow for January & 64 & 64 & 1 & -0.02 & -0.02 & 0.64 & 0.39 & 0.32 & 0.20 & 0.90 & 0.80 & 0.51 & 0.07 \\
\hline ML2 & Mean minimum monthly flow for February & 64 & 64 & 1 & -0.04 & -0.03 & 0.57 & 0.34 & 0.31 & 0.18 & 0.90 & 0.82 & 0.50 & 0.07 \\
\hline
\end{tabular}


ML3 Mean minimum monthly flow for March

ML4 Mean minimum monthly flow for April

ML5 Mean minimum monthly flow for May

ML6 Mean minimum monthly flow for June

ML7 Mean minimum monthly flow for July

ML8 Mean minimum monthly flow for August

ML9 Mean minimum monthly flow for Septembe

ML10 Mean minimum monthly flow for October

ML11 Mean minimum monthly flow for November

ML12 Mean minimum monthly flow for December

ML13 Coefficient of variation in minimum monthly flows

ML14 Mean of the lowest annual daily flow divided by median annual daily flow

averaged across all years

ML15 Mean of the lowest annual daily flow divided by mean annual daily flow averaged across all years

ML16 Median of the lowest annual daily flows divided by median annual daily flows averaged across all years

ML17 Seven-day minimum flow divided by mean annual daily flows averaged across all

ML18 Coefficient of variation in ML17

ML19 Mean of the ratio of the lowest annual daily flow to the mean annual daily flow times 100 averaged across all years

ML20 Ratio of base flow volume to total flow volume

ML21 Coefficient of variation in annual minimum flows averaged across all years

ML22 Mean annual minimum flows divided by catchment area

MH1 Mean of the maximum monthly flows for January

MH2 Mean of the maximum monthly flows for February

MH3 Mean of the maximum monthly flows for March

$\mathrm{MH} 4$ Mean of the maximum monthly flows for April

MH5 Mean of the maximum monthly flows for May

monthly flows for May

MH7 Mean of he maxim

MH7 Mean of the maxim

MH8 Mean of the maximum monthly flows for August

MH9 Mean of the maximnin monthy flows for September

MH10 Mean of the maximum monthly flows for October

MH11 Mean of the maximum monthly flows for November

MH12 Mean of the maximum monthly flows for December

MH14 Median of the highest annual daily flow divided by the median annual daily flow $64 \quad 62$ averaged across all years

MH15 Mean of the 1st percentile from the flow duration curve divided by median daily $64 \quad 64$ flow across all years

MH16 Mean of the 10th percentile from the flow duration curve divided by median daily 6462 flow across all years

MH17 Mean of the 25th percentile from the flow duration curve divided by median daily $64 \quad 54$ flow across all years

MH18 Coefficient of variation of logarithmic annual maximum flows $\quad 6460$

$64 \quad 54$

$64 \quad 63$

MH21 Mean of the high flow volume (alculated as the area between the hydrograph and 6464 the upper threshold during the high flow event) divided by median annual daily flow across all years. The upper threshold is defined as median annual flow

$\begin{array}{lllllll}\text { MH22 Mean of the high flow volume (calculated as the area between the hydrograph and } & 64 & 64 & 1 & 0.00 & 0.00\end{array}$ the upper threshold during the high flow event) divided by median annual daily flow across all years. The upper threshold is defined as 3 times median annual flow

MH23 Mean of the high flow volume (calculated as the area between the hydrograph and $\begin{array}{llllll}64 & 64 & 0 & 1.84 & 0.04\end{array}$ the upper threshold during the high flow event) divided by median annual daily

flow across all years. The upper threshold is defined as 7 times median annual flow

MH24 Mean of the high peak flow during the high flow event (defined by the upper

$8.46 \quad 0.14$

$\begin{array}{lll}0 & 17.87 & 0.08 \\ 0 & 25.87 & 0.10 \\ 1 & 0.00 & 0.00 \\ 1 & -0.05 & -0.02 \\ 1 & 0.03 & 0.01 \\ 1 & 0.04 & 0.02 \\ 1 & 0.12 & 0.05 \\ 1 & 0.11 & 0.05 \\ 1 & 0.02 & 0.01 \\ 1 & 0.00 & 0.00 \\ 0 & -0.85 & -0.02 \\ 0 & 0.00 & 0.01\end{array}$

$66.64 \quad 0.31$

$\begin{array}{ll}74.42 & 0.29\end{array}$

$\begin{array}{ll}0.55 & 0.27 \\ 0.64 & 0.27\end{array}$

$\begin{array}{ll}1.02 & 0.41 \\ 0.95 & 0.38\end{array}$

$0.95-0.40$

$0.84 \quad 0.37$

$\begin{array}{ll}0.73 & 0.41 \\ 0.73 & 0.44\end{array}$

$\begin{array}{ll}0.73 & 0.97 \\ 0.06 & 0.42\end{array}$

$\begin{array}{ll}0.00 & 0.03\end{array}$

0.02

0.06

0.22

$\begin{array}{ll}0.01 & 0.02\end{array}$

$0.01 \quad 0.05$

0.03

0.39

$\begin{array}{ll}0.04 & 0.02 \\ 0.02 & 0.01\end{array}$

0.67

$\begin{array}{ll}0.00 & 0.02 \\ 5.30 & 0.03\end{array}$

$\begin{array}{ll}5.30 & 0.03 \\ 0.01 & 0.09\end{array}$

$293.63 \quad 0.12$

$\begin{array}{ll}191.50 & 0.07\end{array}$

$262.33 \quad 0.07$

$437.31 \quad 0.12$

328.690 .09

$193.09 \quad 0.10$

$\begin{array}{ll}-0.02 & -0.01 \\ -0.10 & -0.05\end{array}$

$125.20 \quad 0.14$

$\begin{array}{ll}-0.11 & -0.08\end{array}$

$\begin{array}{cc}-0.09 & -0.07 \\ 515.04 & 0.18\end{array}$

$\begin{array}{ll}515.04 & 0.18 \\ 0.01 & 0.07\end{array}$

$\begin{array}{lll}0 & 3.50 & 0.11\end{array}$

$\begin{array}{lll}0 & 0.21 & 0.05\end{array}$

$\begin{array}{lll}0 & 0.09 & 0.09\end{array}$

$\begin{array}{lll}0 & 0.36 & 0.13\end{array}$

$\begin{array}{lll}2.62 & 0.00 & -0.01\end{array}$

$\begin{array}{lll}0 & 1.28 & 0.05 \\ 0 & 13.01 & 0.12\end{array}$

$\begin{array}{lll}0 & 1.28 & 0.05 \\ 0 & 13.01 & 0.12\end{array}$

54.01

$\begin{array}{ll}54.01 & 0.35 \\ 0.04 & 0.44\end{array}$

$\begin{array}{ll}0.08 .71 & 0.40 \\ 1047.22 & 0.38\end{array}$

$1095.46 \quad 0.31$

$1201.51 \quad 0.33$

$\begin{array}{ll}242.02 & 0.35\end{array}$

$844.68 \quad 0.42$

$\begin{array}{ll}0.70 & 0.47\end{array}$

$\begin{array}{ll}0.54 & 0.29\end{array}$

$\begin{array}{ll}376.81 & 0.42 \\ 0.74 & 0.52\end{array}$

$0.85 \quad 0.63$

$1292.24 \quad 0.46$

$0.11-0.73$

$38.64 \quad 0.64$

$\begin{array}{ll}21.94 & 0.70\end{array}$

$2.20 \quad 0.53$

$0.61 \quad 0.55$

$\begin{array}{ll}1.48 & 0.56\end{array}$

$\begin{array}{ll}0.22 & 0.98\end{array}$

$10.37 \quad 0.38$

60.95

0.38
0.57

0.55

0.71

31.77

0.73

12.88

0.72

$6.83 \quad 0.38$
$0.56 \quad 0.62$

$\begin{array}{ll}180.01 \quad 0.08 \\ 204.79 & 0.08\end{array}$

$204.79 \quad 0.08$

$\begin{array}{ll}0.49 & 0.07 \\ 0.56 & 0.08\end{array}$

$\begin{array}{ll}0.63 & 0.09\end{array}$

$0.67 \quad 0.09$

$\begin{array}{ll}0.66 & 0.09 \\ 0.61 & 0.09\end{array}$

$0.57 \quad 0.08$

$0.55 \quad 0.08$

$19.51 \quad 0.15$

$0.05 \quad 0.14$

$0.09 \quad 0.15$

$0.05 \quad 0.14$

$0.49 \quad 0.18$

$0.61 \quad 0.16$

$0.05 \quad 0.11$
78.27

$\begin{array}{ll}78.27 & 0.17\end{array}$

$\begin{array}{ll}0.07 & 0.13\end{array}$

$\begin{array}{ll}1395.83 & 0.12 \\ 1400.17 & 0.11\end{array}$

$\begin{array}{ll}1744.35 & 0.12\end{array}$

$1995.83 \quad 0.11$

$2066.25 \quad 0.12$

$1084.08 \quad 0.10$

$\begin{array}{ll}1084.08 & 0.10 \\ 0.59 & 0.10\end{array}$

$\begin{array}{ll}0.59 & 0.10 \\ 0.62 & 0.08\end{array}$

$\begin{array}{ll}0.62 & 0.08 \\ 59278 & 0.11\end{array}$

$\begin{array}{ll}592.78 & 0.11 \\ 0.79 & 0.11\end{array}$

$0.79 \quad 0.11$

$\begin{array}{ll}0.64 & 0.10 \\ 1340.80 & 0.15\end{array}$

$1340.80 \quad 0.15$

$\begin{array}{ll}0.10 & 0.16 \\ 42.39 & 0.14\end{array}$

$23.19 \quad 0.13$

$3.83 \quad 0.10$

$0.85 \quad 0.11$

$0.22 \quad 0.19$

$\begin{array}{ll}8.15 & 0.11 \\ 101.61 & 0.12\end{array}$

$0.05 \quad 0.54$

$\begin{array}{ll}0.77 & 0.81 \\ 0.27 & 0.75\end{array}$

$0.46 \quad 0.12$

$58.49 \quad 0.11$

$12.86 \quad 0.16$

(continued on next page) 


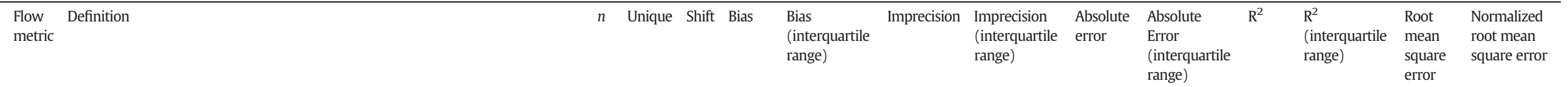
range)

threshold) divided by median annual daily flow. The upper threshold is defined as

median annual flow

MH25 Mean of the high peak flow during the high flow event (defined by the upper threshold) divided by median annual daily flow. The upper threshold is defined as 3

MH26 Mean of the high peak flow during the high flow event (defined by the upper threshold) divided by median annual daily flow. The upper threshold is defined as 7 times median annual flow

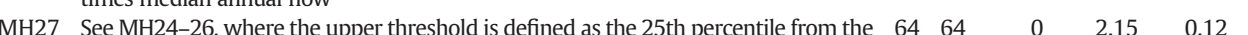
flow duration curve

FL1 Number of annual occurrences during which the magnitude of flow remains below $\begin{array}{cllllll}64 & 59 & 1 & -0.01 & -0.04\end{array}$ a lower threshold. Hydrologic pulses are defined as those periods within a year in which the flow drops below the 25th percentile (low pulse) of all daily values for the time period

FL2 Coefficient of variation in FL1 $\begin{array}{llllll}64 & 64 & 0 & 0.26 & 0.02\end{array}$ by the record length in years

FH1 See FL1, where the high pulse is defined as the 75th percentil

3. See FH1, where the upper threshold is defined as 3 times median daily flow, and $\begin{array}{llllll}64 & 64 & 0 & -0.18 & -0.02\end{array}$

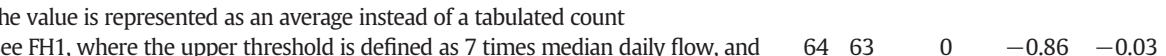

FH4 See FH1, where the upper threshold is defined as 7 times median daily flow, and the value is represented as an average instead of a tabulated count

FH5 Mean number of high flow events per year using an upper threshold of median flow over all years

FH6 Mean number of high flow events per year using an upper threshold of 3 times median flow over all years

FH7 Mean number of high flow events per year using an upper threshold of 7 times median flow over all years

FH8 See FH5-7, where the 25th percentile is used as the upper threshold

FH9 See FH5-7, where the 75th percentile is used as the upper threshold

FH11 Mean number of discrete flood events per mis

DL1 Annual minima of mean of daily discharge

DL2 Annual minima of 3-day mean of daily discharge

DL3 Annual minima of 7-day mean of daily discharge

DL4 Annual minima of 30-day mean of daily discharge

DL5 Annual minima of 90-day mean of daily discharge

DL6 Coefficient of variation in mean of daily discharge

DL7 Coefficient of variation in 3-day mean of daily discharge

DL8 Coefficient of variation in 7-day mean of daily discharge

DL9 Coefficient of variation in 30-day mean of daily discharg

DL10 Coefficient of variation in 90-day mean of daily discharg

DL11 Mean annual 1-day minimum, divided by median flow

DL12 Mean annual 7-day minimum, divided by median flow

DL13 Mean annual 30-day minimum, divided by median flow

DL14 Mean magnitude of flows exceeded $75 \%$ of the time (calculated from the flow duration curve) divided by median daily flow, overall years

DL15 Mean magnitude of flows exceeded 90\% of the time (calculated from the flow duration curve) divided by median daily flow, overall years

DL16 Mean duration of FL1

DL17 Coefficient of variation in DL16

DL18 Mean annual number of days having zero daily flow

DL19 Coefficient of variation in DL18 $\begin{array}{lllll}64 & 56 & 0 & -0.10 & -0.04\end{array}$

$64 \quad 64$

$64 \quad 64$

$\begin{array}{ll}64 & 62 \\ 64 & 54\end{array}$

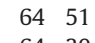

$\begin{array}{ll}64 & 30\end{array}$

6461

6460

$64 \quad 63$

$\begin{array}{lll}64 \quad 62 \\ 64 & 64\end{array}$

$\begin{array}{ll}64 & 64 \\ 61 & 61\end{array}$

$\begin{array}{ll}61 & 61 \\ 61 & 61\end{array}$

$\begin{array}{ll}61 & 61\end{array}$

$62 \quad 62$

63

$\begin{array}{ll}64 & 64\end{array}$

$\begin{array}{lll}64 & 33\end{array}$

$\begin{array}{ll}64 & 30\end{array}$

$\begin{array}{ll}64 & 33\end{array}$

$64 \quad 41$

$64 \quad 32$

6462

$64 \quad 63$

6432

$\begin{array}{ll}64 & 33\end{array}$ $\begin{array}{lll}-0.10 & -0.04 \\ 0 & 0.02 & 0.01\end{array}$

$-0.06-0.01$

$\begin{array}{ll}-0.01 & -0.02 \\ 0.08 & 0.05\end{array}$

$\begin{array}{ll}0.08 & 0.05\end{array}$

$0.05 \quad 0.15$

$\begin{array}{ll}0.00 & 0.02\end{array}$

$\begin{array}{ll}0.13 & 0.04\end{array}$

$\begin{array}{ll}0.14 & 0.05\end{array}$

$0.13 \quad 0.05$

$\begin{array}{ll}0.07 & 0.03 \\ 0.06 & 0.04\end{array}$

$\begin{array}{ll}0.06 & 0.04 \\ 5.39 & 0.04\end{array}$

$\begin{array}{ll}8.26 & 0.06\end{array}$

$\begin{array}{ll}4.02 & 0.03\end{array}$

$\begin{array}{ll}-0.04 & -0.04 \\ 0.01 & 0.02\end{array}$

$\begin{array}{ll}-0.01 & 0.02 \\ 0.01 & 0.03\end{array}$

$\begin{array}{ll}0.00 & 0.01\end{array}$

$\begin{array}{ll}0.00 & -0.01\end{array}$

$0.01 \quad 0.03$

$0.01 \quad 0.02$

$\begin{array}{ll}-1.69 & -0.08 \\ 0.02 & 0.01\end{array}$

$\begin{array}{ll}0.02 & 0.01 \\ 0.06 & 0.01\end{array}$
$7.93 \quad 0.05$
8.26
$10.41 \quad 0.58$

0.58

0.33

11.42

0.17

0.65

0.60

6.11

0.34

$0.56 \quad 0.66$

$12.64 \quad 0.16$

0.68

0.17

0.34

$0.65 \quad 0.66$

0.27

0.14

$\begin{array}{llllll}6.18 & 0.35 & 0.54 & 0.65 & 14.04 & 0.16 \\ 0.09 & 0.30 & 0.40 & 0.70 & 0.15 & 0.19\end{array}$

$9.24 \quad 0.76$

$28.21-0.28$

$\begin{array}{ll}0.14 & 0.48\end{array}$

$5.77 \quad 0.61$

$\begin{array}{ll}19.38 & 0.66\end{array}$

$13.42 \quad 0.54$

1.34

1.61

1.88

$0.14 \quad 0.49$

$\begin{array}{ll}0.14 & 0.49 \\ 1.02 & 0.63\end{array}$

0.18
0.07

1.15

0.97

1.01
0.99

0.99

0.70
48.75

$\begin{array}{ll}48.75 & 0.32 \\ 51.51 & 0.35\end{array}$

$\begin{array}{ll}51.51 & 0.35 \\ 47.76 & 0.33\end{array}$

$\begin{array}{ll}37.73 & 0.30\end{array}$

$\begin{array}{ll}0.38 & 0.39 \\ 0.07 & 0.29\end{array}$

$0.07 \quad 0.30$

$0.11 \quad 0.34$

$0.09 \quad 0.35$

$0.10 \quad 0.32$

$\begin{array}{ll}0.24 & 0.62\end{array}$

$\begin{array}{ll}0.24 .10 & 0.75\end{array}$

0.82

0.82
1.28

0.75
0.31
0.25

0.25

\begin{tabular}{ll}
5.27 & 0.43 \\
15.31 & 0.15 \\
& \\
0.07 & 0.25 \\
3.15 & 0.33 \\
9.67 & 0.33 \\
& \\
6.58 & 0.27 \\
& \\
0.69 & 0.30 \\
& \\
0.83 & 0.30 \\
& \\
0.97 & 0.23 \\
& \\
0.07 & 0.26 \\
0.51 & 0.31 \\
0.10 & 0.32 \\
0.04 & 0.38 \\
0.53 & 0.18 \\
0.51 & 0.17 \\
0.51 & 0.18 \\
0.50 & 0.19 \\
0.39 & 0.23 \\
25.22 & 0.17 \\
25.23 & 0.17 \\
22.69 & 0.16 \\
21.96 & 0.17 \\
0.23 & 0.23 \\
0.04 & 0.15 \\
0.04 & 0.15 \\
0.06 & 0.17 \\
0.05 & 0.18 \\
& \\
0.05 & 0.16 \\
& \\
0.10 & 0.27 \\
7.58 & 0.37 \\
0.43 & 0.16 \\
0.62 & 0.12 \\
\hline
\end{tabular}

$\begin{array}{ll}7.58 & 0.37 \\ 0.62 & 0.16 \\ 0.12\end{array}$

$\begin{array}{llll}0.58 & 0.57 & 7.72 & 0.14 \\ 0.71 & 0.85 & 27.09 & 0.16 \\ & & & \\ 0.70 & 0.75 & 0.12 & 0.12 \\ 0.50 & 0.67 & 4.99 & 0.15 \\ 0.70 & 0.67 & 14.59 & 0.12 \\ & & & \\ 0.67 & 0.73 & 11.09 & 0.11 \\ & & & \\ 0.44 & 0.70 & 1.17 & 0.15 \\ & & & \\ 0.66 & 0.70 & 1.38 & 0.12 \\ & & & \\ 0.76 & 0.77 & 1.57 & 0.12 \\ & & & \\ 0.69 & 0.74 & 0.12 & 0.12 \\ 0.43 & 0.69 & 0.93 & 0.19 \\ 0.32 & 0.68 & 0.18 & 0.17 \\ 0.10 & 0.62 & 0.06 & 0.22 \\ 0.88 & 0.82 & 0.71 & 0.10 \\ 0.88 & 0.83 & 0.70 & 0.10 \\ 0.88 & 0.82 & 0.69 & 0.10 \\ 0.88 & 0.81 & 0.68 & 0.09 \\ 0.89 & 0.77 & 0.54 & 0.08 \\ 0.55 & 0.83 & 70.26 & 0.19 \\ 0.54 & 0.83 & 72.15 & 0.18 \\ 0.53 & 0.84 & 66.61 & 0.18 \\ 0.64 & 0.83 & 46.65 & 0.17 \\ 0.68 & 0.77 & 0.34 & 0.14 \\ 0.76 & 0.85 & 0.09 & 0.15 \\ 0.75 & 0.85 & 0.08 & 0.16 \\ 0.76 & 0.83 & 0.10 & 0.15 \\ 0.73 & 0.82 & 0.08 & 0.16 \\ & & & \\ 0.75 & 0.84 & 0.10 & 0.16 \\ & & & \\ 0.42 & 0.73 & 0.19 & 0.18 \\ 0.16 & 0.63 & 12.97 & 0.20 \\ 0.62 & 0.84 & 0.96 & 0.21 \\ 0.62 & 0.88 & 1.61 & 0.27\end{array}$

$\begin{array}{llll}0.62 & 0.84 & 0.96 & 0.21 \\ 0.62 & 0.88 & 1.61 & 0.27\end{array}$ 
DL20 Percentage of all months with zero flow

DH1 Annual maxima of mean of daily discharge

DH2 Annual maxima of 3-day mean of daily discharge

DH3 Annual maxima of 7-day mean of daily discharge

DH4 Annual maxima of 30-day mean of daily discharge

DH5 Annual maxima of 90-day mean of daily discharge

DH6 Coefficient of variation in annual maxima of mean daily discharge

DH7 Coefficient of variation in annual maxima of 3-day mean of daily discharge

DH8 Coefficient of variation in annual maxima of 7-day mean of daily discharge

DH9 Coefficient of variation in annual maxima of 30-day mean of daily discharge

DH10 Coefficient of variation in annual maxima of 90-day mean of daily discharge

DH11 Mean annual 1-day maximum, divided by median flow

DH12 Mean annual 7-day maximum, divided by median flow

DH13 Mean annul 30-day maximum, divided by median flow

DH14 Monthly flow equalled or exceeded 95\% of the time divided by mean monthly flow 6452

DH15 Mean duration of FH1

DH16 Coefficient of variation in DH15 64

DH17 See DH15, where the upper threshold is defined as 1 times median flows, and the $\quad 64 \quad 64$ value is represented as an average instead of a tabulated coun

DH18 See DH15, where the upper threshold is defined as 3 times median flows, and the 6462 value is represented as an average instead of a tabulated coun

DH19 See DH15, where the upper threshold is defined as 7 times median flows, and the $64 \quad 59$

DH20 See DH17-19, where the upper threshold is defined as the 25th percentile of median flows

DH21 See DH17-19, where the upper threshold is defined as the 75th percentile of median flows

Mean annual median interval in days between floods overall years across all years

floods occurred over all years

TA1 Constancy

TA2 Predictability of flow

Teasonal predictability of flooding

TL1 Julian date of annual minimum

TL2 Variability in Julian date of annual minimum

TL3 Seasonal predictability of low flow

TL4 Seasonal predictability of non-low flow

TH1 Julian date of annual maximum

TH2 Variability in Julian date of annual maximum

TH3 Seasonal predictability of non-flooding

RA1 Rise rate

RA2 Variability in rise rate

RA3 Fall rate

RA4 Variability in fall rate

RA5 No day rises

RA6 Change of flow (increasing flow)

RA7 Change of flow (decreasing flow)

RA8 Reversals

RA9 Variability in reversals
$64 \quad 62$

$64 \quad 61$

$64 \quad 63$

$\begin{array}{lllll}64 & 18 & 1 & 0.03 & 0.01\end{array}$

64

$64 \quad 62$

63

63

64

(1)

(1)

1
1

1

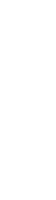

$\begin{array}{ll}598.82 & 0.09 \\ -0.10 & -0.07\end{array}$

$\begin{array}{ll}-0.10 & -0.07 \\ 103.87 & 0.07\end{array}$

$\begin{array}{ll}103.87 & 0.07 \\ 61.35 & 0.06\end{array}$

$\begin{array}{ll}0.00 & -0.01 \\ 0.01 & 0.03\end{array}$

$\begin{array}{ll}0.00 & -0.01 \\ 0.01 & 0.03\end{array}$

$\begin{array}{ll}0.01 & 0.03\end{array}$

$\begin{array}{ll}11.05 & 0.12\end{array}$

\begin{tabular}{ll}
$1.51 \quad 0.06$ \\
\hline
\end{tabular}

$0.46 \quad 0.05$

$\begin{array}{ll}0.00 & 0.00 \\ 0.32 & 0.13\end{array}$

$\begin{array}{ll}0.32 & 0.13 \\ -0.01 & -0.02\end{array}$

$\begin{array}{ll}0.03 & 0.08\end{array}$

$\begin{array}{ll}0.31 & 0.09\end{array}$

$0.09 \quad 0.06$

$0.01 \quad 0.04$

$\begin{array}{ll}-0.02 & -0.05\end{array}$

$0.27 \quad 0.03$
0.01

$\begin{array}{ll}-0.02 & -0.09\end{array}$

6433

$\begin{array}{ll}64 & 64 \\ 64 & 25\end{array}$

$64 \quad 25$

$64 \quad 64$

$\begin{array}{ll}64 & 63 \\ 64 & 4\end{array}$

$\begin{array}{ll}64 & 5\end{array}$

$64 \quad 64$

$64 \quad 62$

$\begin{array}{ll}64 & 32\end{array}$

$64 \quad 64$

$64 \quad 64$

$64 \quad 64$

$\begin{array}{ll}64 & 64 \\ 64 & 15\end{array}$

$\begin{array}{ll}64 & 15 \\ 64 & 37\end{array}$

64 -

$64 \quad 63$

$\begin{array}{ll}64 & 63\end{array}$ $\begin{array}{ll}-0.04 & 0.00 \\ 0.00 & 0.00\end{array}$

$\begin{array}{ll}0.57 & 0.27 \\ 0.52 & 0.41 \\ 1963.84 & 0.31 \\ 0.49 & 0.35 \\ 465.67 & 0.30 \\ 292.05 & 0.29 \\ 0.21 & 0.78 \\ 0.19 & 0.79 \\ 0.15 & 0.60 \\ 8.15 & 0.68 \\ 7.07 & 0.61 \\ 58.90 & 0.66 \\ 18.25 & 0.78 \\ 6.44 & 0.67 \\ 0.35 & 0.71 \\ 1.67 & 0.68 \\ 0.24 & 0.61 \\ 0.22 & 0.68 \\ & \\ 2.53 & 0.71 \\ & \\ 1.03 & 0.70 \\ & \\ 0.15 & 0.48 \\ & \\ 0.28 & 0.77 \\ & \\ 9.96 & 1.14 \\ 0.06 & 0.74 \\ & \\ 0.15 & 0.87 \\ & \\ 0.08 & 0.37 \\ 7.77 & 0.44 \\ 0.07 & 0.78 \\ 0.03 & 0.71 \\ 5.79 & 0.76 \\ 0.01 & 0.57 \\ 0.01 & 0.81 \\ 0.24 & 0.63 \\ 5.54 & 0.82 \\ 0.13 & 0.80 \\ 0.52 & 0.38 \\ 0.15 & 0.71 \\ 44.26 & 0.36 \\ 92.60 & 0.88 \\ 0.02 & 0.80 \\ 0.06 & 0.41 \\ 0.02 & 0.26 \\ 0.10 & 0.86 \\ 3.82 & 1.03 \\ & \end{array}$

$\begin{array}{lll}1 & 0.00 & -0.02 \\ 0 & 0.19 & 0.05\end{array}$

\begin{tabular}{|c|c|}
\hline .27 & 0.32 \\
\hline .41 & 0.28 \\
\hline 31 & 1119.05 \\
\hline 0.35 & 0.23 \\
\hline .30 & 266.65 \\
\hline .29 & 152.40 \\
\hline .78 & 0.10 \\
\hline ..79 & 0.09 \\
\hline .60 & 0.07 \\
\hline .68 & 4.15 \\
\hline .61 & 3.46 \\
\hline .66 & 29.43 \\
\hline ..78 & 8.49 \\
\hline .67 & 3.40 \\
\hline .71 & 0.17 \\
\hline .68 & 0.92 \\
\hline .61 & 0.12 \\
\hline .68 & 0.11 \\
\hline 71 & 1.35 \\
\hline 70 & 0.48 \\
\hline 48 & 0.08 \\
\hline 77 & 0.14 \\
\hline 14 & 4.58 \\
\hline 74 & 0.03 \\
\hline .87 & 0.08 \\
\hline .37 & 0.04 \\
\hline 44 & 3.80 \\
\hline 78 & 0.03 \\
\hline .71 & 0.02 \\
\hline .76 & 2.69 \\
\hline .57 & 0.00 \\
\hline .81 & 0.00 \\
\hline .63 & 0.12 \\
\hline .82 & 2.78 \\
\hline .80 & 0.07 \\
\hline 0.38 & 0.28 \\
\hline .71 & 0.08 \\
\hline .36 & 26.46 \\
\hline .88 & 47.73 \\
\hline .80 & 0.01 \\
\hline .41 & 0.03 \\
\hline .26 & 0.01 \\
\hline 86 & 0.05 \\
\hline 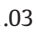 & 1.88 \\
\hline
\end{tabular}

\begin{tabular}{llll}
0.50 & 0.85 & 0.86 & 0.24 \\
0.85 & 0.78 & 0.49 & 0.09 \\
0.69 & 0.83 & 3333.27 & 0.10 \\
0.87 & 0.83 & 0.51 & 0.08 \\
0.68 & 0.83 & 1040.77 & 0.10 \\
0.72 & 0.85 & 598.47 & 0.10 \\
0.18 & 0.62 & 0.20 & 0.18 \\
0.21 & 0.60 & 0.18 & 0.15 \\
0.30 & 0.72 & 0.17 & 0.14 \\
0.46 & 0.65 & 6.66 & 0.16 \\
0.55 & 0.70 & 5.68 & 0.14 \\
0.63 & 0.67 & 52.95 & 0.14 \\
0.50 & 0.64 & 18.51 & 0.12 \\
0.46 & 0.64 & 7.41 & 0.11 \\
0.63 & 0.64 & 0.27 & 0.14 \\
0.56 & 0.62 & 1.23 & 0.15 \\
0.56 & 0.70 & 0.23 & 0.13 \\
0.46 & 0.65 & 0.18 & 0.13 \\
& & & \\
0.23 & 0.62 & 3.03 & 0.15 \\
& & & \\
0.44 & 0.67 & 1.37 & 0.10 \\
& & & \\
0.70 & 0.74 & 0.14 & 0.12 \\
& & & \\
0.45 & 0.62 & 0.21 & 0.16 \\
& & & \\
0.02 & 0.48 & 7.76 & 0.19 \\
0.39 & 0.60 & 0.06 & 0.14 \\
& & & \\
0.22 & 0.53 & 0.13 & 0.16 \\
& & & \\
0.82 & 0.81 & 0.07 & 0.14 \\
0.79 & 0.78 & 6.27 & 0.13 \\
0.03 & 0.63 & 0.05 & 0.26 \\
0.60 & 0.64 & 0.03 & 0.12 \\
0.28 & 0.65 & 5.84 & 0.16 \\
0.23 & 0.69 & 0.01 & 0.21 \\
0.56 & 0.58 & 0.01 & 0.16 \\
0.22 & 0.69 & 0.46 & 0.13 \\
0.16 & 0.59 & 4.78 & 0.17 \\
-0.04 & 0.58 & 0.10 & 0.26 \\
0.82 & 0.80 & 0.49 & 0.10 \\
0.34 & 0.61 & 0.13 & 0.15 \\
0.68 & 0.79 & 64.04 & 0.12 \\
0.24 & 0.55 & 68.41 & 0.18 \\
0.63 & 0.58 & 0.02 & 0.11 \\
0.73 & 0.80 & 0.06 & 0.11 \\
0.67 & 0.85 & 0.03 & 0.10 \\
0.19 & 0.53 & 0.08 & 0.19 \\
0.20 & 0.50 & 4.14 & 0.15 \\
\hline & & &
\end{tabular}




\section{References}

Acuna, V., Munoz, I., Giorgi, A., Omella, M., Sabater, F., Sabater, S., 2005. Drought and post drought recovery cycles in an intermittent Mediterranean stream: structural and functional aspects. J. N. Am. Benthol. Soc. 24, 919-933.

Armstrong, D.S., Richards, T.A., Levin, S.B., 2011. Factors influencing riverine fish assemblages in Massachusetts. US Geological Survey Scientific-Investigations Report 2011-5193 (58p). http://pubsusgsgov/sir/2011/5193/.

Arthington, A.H., Bunn, S.E., Poff, N.L., Naiman, R.J., 2006. The challenge of providing environmental flow rules to sustain river ecosystems. Ecol. Appl. 16, 1311-1318.

Barbour, M.T., Gerritsen, J., Snyder, B.D., Stribling, J.B., 1999. Rapid Bioassessment Protocols for Use in Streams and Wadeable Rivers: Periphyton, Benthic Macroinvertebrates and Fish. Second edition. US Environmental Protection Agency; Office of Water, Washington, DC EPA 841-B-99-002.

Beche, L.A., Connors, P.G., Resh, V.H., Merenlender, A.M., 2009. Resilience of fishes and invertebrates to prolonged drought in two California streams. Ecography 32, 778-788.

Belmar, O., Velasco, J., Martinez-Chapel, F., 2011. Hydrological classification of natural flow regimes to support environmental flow assessments in intensively regulated Mediterranean rivers, Segura River basin (Spain). Environ. Manag. 47, 992-1004.

Beniston, M., Stephenson, D.B., Christensen, O.B., Ferro, C.A.T., Frei, C., Goyette, S., Halsnaes, K., Holt, T., Jylha, K., Koffi, B., Palutikof, J., Scholl, R., Semmier, T., Woth, K., 2007. Future extreme events in European climate: an exploration of regional climate model projections. Climate Change 81, 71-95.

Buchanan, C., Moltz, H.L.N., Haywood, H.C., Planner, J.B., Griggs, A.N., 2013. A test of the ecological limits of hydrologic alteration (ELOHA) method for determining environmental flows in the Potomac River basin, USA. Freshw. Biol. 58, 2632-2647.

Bunn, S.E., Arthington, A.H., 2002. Basic principles and ecological consequences of altered flow regimes for aquatic biodiversity. Environ. Manag. 30, 492-507.

Caiola, N., Ibanez, C., Verdu, J., Munne, A., 2014. Effects of flow regulation on the establishment of alien fish species: a community structure approach to biological validation of environmental flows. Ecol. Indic. 45, 598-604.

Carlisle, D.M., Wolock, D.M., Meador, M.R., 2010. Alteration of streamflow magnitudes and potential ecological consequences: a multiregional assessment. Front. Ecol. Environ. 9, 264-270.

Chester, E.T., Robson, B.J., 2011. Drought refuges, spatial scale and reocolonization by invertebrates in non-perennial streams. Freshw. Biol. 56, 2094-2104.

Chester, E.T., Matthews, T.G., Howson, T.J., Johnston, K., Mackie, J.K., Strachan, S.R., Robson, B.J., 2014. Constraints upon the response of fisha dn crayfish to environmental flow releases in a regulated headwater stream network. PLoS One 9 (3), e91925. https:// doi.org/10.1371/journal.pone.0091925.

Christensen, M.R., Graham, M.D., Vinebrooke, R.D., Findlay, D.L., Paterson, M.J., Turner, M.A., 2006. Multiple anthropogenic stressors cause ecological surprises in boreal lakes. Glob. Chang. Biol. 12, 2316-2322.

Closs, G.P., Lake, P.S., 1996. Drought, differential mortality and the coexistence of a native fish (Galaxias olidus) and trout (Salmo trutta) in an intermittent stream. Environ. Biol. Fish 47, 17-26.

Craven, S.W., Peterson, J.T., Freeman, M.C., Kwak, J.T., Irwin, E., 2010. Modeling the relations between flow regime components, species traits, and spawning success of fishes in warmwater streams. Environ. Manag. 46, 181-194.

Dauwalter, D.C., Pert, E.J., 2003. Effect of electrofishing effort on an index of biotic integrity. N. Am. J. Fish Manag. 23, 1247-1252.

Dauwalter, D.C., Pert, E.J., Keith, W.E., 2003. An index of biotic integrity for fish assemblages in Ozark Highland streams of Arkansas. Southeast. Nat. 2, 447-468.

Dekar, M.P., Magoulick, D.D., 2007. Factors affecting fish assemblage structure during seasonal stream drying. Ecol. Freshw. Fish 16, 335-342.

DiStefano, R.J., Magoulick, D.D., Imhoff, E.M., Larson, E.R., 2009. Imperiled crayfishes use hyporheic zone during seasonal drying of an intermittent stream. J. N. Am. Benthol. Soc. $28,142-152$.

Dodds, W.K., Gido, K.B., Whiles, M.R., Fritz, K.M., Matthews, W.J., 2004. Life on the edge: the ecology of Great Plains prairie streams. Bioscience 54, 205-216.

Falcone, J.A., Carlisle, D.M., Weber, L.C., 2010. Quantifying human disturbance in watersheds: variable selection and performance of a GIS-based disturbance index for predicting the biological condition of perennial streams. Ecol. Indic. 10, 264-273.

Farjad, B., Gupta, A., Marceau, D.J., 2015. Hydrological regime responses to climate change for the 2020s and 2050s periods in the Elbow River watershed in southern Alberta, Canada. In: Ramkumar, M., Kumaraswamy, K., Mohanraj, R. (Eds.), Environmental Management of River Basin Ecosystems. Springer, pp. 65-89.

Fausch, K.D., Taniguchi, Y., Nakano, S., Grossman, G.D., Townsend, C.R., 2001. Flood disturbance regimes influence rainbow trout invasion success among five Holarctic regions. Ecol. Appl. 11, 1438-1455.

Fritz, K.M., Dodds, W.K., 2005. Harshness: characterization of intermittent stream habitat over space and time. Mar. Freshw. Res. 56, 13-23.

Gehrke, P.C., Brown, P., Schiller, C.B., 1999. Australian native fish, river regulation and carp: the Paroo perspective. In: Kingsford, R.T. (Ed.), A Free-Flowing River: The Ecology Fo the Paroo River. NSW National Parks and Wildlife Serivce, Hurtsville, Australia, pp. 201-222.

Gillespie, B.R., Desmet, S., Kay, P., Tilloston, M.R., Brown, L.E., 2014. A critical analysis of regulated river ecosystem responses to managed environmental flows from reservoirs. Freshw. Biol. 60, 410-425.

Gwinn, D.C., Beesley, L.S., Close, P., Gawne, B., Davies, P.M., 2016. Imperfect detection and the determination of environmental flows for fish: challenges, implications and solutions. Freshw. Biol. 61, 172-180.

Haggard, B.E., 2010. Phosphorus concentrations, loads, and sources within the Illinois River drainage area, northwest Arkansas, 1997-2008. J. Environ. Qual. 39, 2113-2120.
Harris, G.P., Heathwaite, A.L., 2011. Why is achieving good ecological outcomes in rivers so difficult? Freshw. Biol. 57, 91-107.

Johnson, E., Austin, B.J., Inlander, E., Gallipeau, C., Evans-White, M.A., Entrekin, S., 2015 Stream macroinvertebrate communities across a gradient of natural gas development in the Fayetteville Shale. Sci. Total Environ. 530-531, 323-332.

Karr, J., 1991. Biological integrity: a long-neglected aspect of water resource management Ecol. Appl. 1, 66-84.

Katz, R.A., Freeman, M.C., 2015. Evidence of population resistence to extreme low flows in a fluvial-dependent fish species. Can. J. Fish. Aquat. Sci. 72. https://doi.org/10.1139/ cjfas-2015-0173.

Kendy, E., Apse, C., Blann, K., 2012. A Practical Guide to Environmental Flows for Policy and Planning With Nine Case Studies in the United Sates. The Nature Conservancy http://conserveonline.org/workspaces/eloha/documents/practical-guide-to-environmental-flows-for-policy.

Kennard, M.J., Mackay, S.J., Pusey, B.J., Olden, J.D., Marsh, N., 2010. Quantifying uncertainty in estimation of hydrologic metrics for ecohydrological studies. River Res. Appl. 26, 137-156.

King, A.J., Gawne, B., Beelsey, L., Koehn, J.D., Nielsen, D.L., Price, A., 2015. Improving ecological response monitoring of environmental flows. Environ. Manag. 55, 991-1005.

Lake, P.S., 2000. Disturbance, patchiness, and diversity in streams. J. N. Am. Benthol. Soc. $19,573-592$.

Larson, E.R., Olden, J.D., 2010. Latent extinction and invasion risk of crayfishes in the southeastern United States. Conserv. Biol. 24, 1099-1110.

Larson, E.R., Magoulick, D.D., Turner, C., Laycock, K.H., 2009. Disturbance and species displacement: different tolerances to stream drying and desiccation in a native and an invasive crayfish. Freshw. Biol. 54, 1899-1908.

Leasure, D.R., Magoulick, D.D., Longing, S.D., 2016. Natural flow regimes of the OzarkOuachita Interior Highlands Region. River Res. Appl. 32, 18-35.

Liaw, A., Wiener, M., 2002. Classification and regression by randomForest. R News 2 (3), $18-22$.

Lynch, D.T., Leasure, D.R., Magoulick, D.D., 2018. The influence of drought on flow-ecology relationships in Ozark Highland streams. Freshw. Biol. 2018, 1-23. https://doi.org/ 10.1111/fwb.13089.

Lytle, D.A., 2008. Life-history and behavioral adaptations to flow regime in aquatic insects. In: Lancaster, J., Briers, R.A. (Eds.), Aquatic Insects: Challenges to Populations. CABI International, pp. 122-138.

Magoulick, D.D., DiStefano, R.J., 2007. Invasive crayfish Orconectes neglectus threatens native crayfishes in the Spring River drainage of Arkansas and Missouri. Southeast. Nat. 6, 141-150.

Magoulick, D.D., Lynch, D.T., 2015. Occupancy and abundance modeling of the endangered yellowcheek darter in Arkansas. Copeia 103, 433-439.

Masson-Delmotte, V., Schulz, M., Abe-Ouchi, A., Beer, J., Ganopolski, A., Gonzalez Rouco, J.F., Timmermann, A., 2013. Information from paleoclimate archives. In: Stocker T.F., Oin, D., Plattner, G.K., Tignor, M., Allen, S.K., Boschung, J., Nauels, A., Xia, Y., Bex, V., Midgley, P.M. (Eds.), Climate Change 2013: The Physical Science Basis. Contribution of Working Group I to the Fifth Assessment Report of the Intergovernmental Panel on Climate Change. Cambridge University Press, Cambridge, United Kingdom and New York, NY, pp. 383-464.

Matthews, W.J., Marsh-Matthews, E., Cashner, R.C., Gelwick, F., 2013. Disturbance and trajectory of change in a stream fish community over four decades. Oecologia 173 955-969.

Matthews, W.J., Marsh-Matthews, E., Adams, G.L., Adams, S.R., 2014. Two catastrophic floods: similarities and differences in effects on an Ozark stream fish community. Copeia 2014, 682-693.

Mazor, R.D., May, J.T., Sengupta, A., McCune, K., Bledsoe, B.P., Stein, E.D., 2018. Tools for managing hydrologic alteration on a regional scale: setting targets to protect stream health. Freshw. Biol. 2018, 1-18. https://doi.org/10.1111/fwb.13062.

McGarvey, D.J., 2014. Moving beyond species-discharge relationships to a flow-mediated, macroecological theory of fish species richness. Freshw. Sci. 33, 18-31.

McManamay, R.A., Frimpong, E.A., 2015. Hydrologic filtering of fish life history strategies across the United States: implications for stream flow alteration. Ecol. Appl. 25, 243-263.

McManamay, R.A., Orth, D.J., Dolloff, C.A., Matthews, D.C., 2014. Application of the ELOHA framework to regulated rivers in the Upper Tennessee River basin: a case study. Environ. Manag. 51, 1210-1235.

Meador, J.R., Peterson, J.T., Wisniewski, J.M., 2011. An evaluation of the factors influencing freshwater mussel capture probability, survival, and temporary emigration in a large lowland river. J. N. Am. Benthol. Soc. 30, 507-521.

Meffe, G.K., 1984. Effects of abiotic disturbance on coexistence of predator-prey fish species. Ecology 65, 1525-1534.

Monk, W.A., Wood, P.J., Hannah, D.M., Wilson, D.A., Extence, C.A., Chadd, R.P., 2006. Flow variability and macroinvertebrate community response within riverine systems. River Res. Appl. 22, 595-615.

Moulton II, S.R., Carter, J.L., Grotheer, S.A., Cuffney, T.F., Short, T.M., 2000. Methods of analysis by the US Geological Survey National Water Quality laboratory - processing, taxonomy, and quality control of benthic macroinvertebrate samples. USGS Open File Report 00-212.

Moulton II, S.R., Kennen, J.G., Goldstein, R.M., Hambrook, J.A., 2002. Revised protocols for sampling algal, invertebrate, and fish communities as part of the National WaterQuality Assessment Program. US Geological Survey Open-File Report 02-150.

[NOAA] National Centers for Environmental Information, 2015. Historical Palmer Drought Indices. Available at. http://www.ncdc.noaa.gov/temp-andprecip/drought/historicalpalmers/, Accessed date: 23 May 2015.

Niu, S.Q., Franczyk, M.P., Knouft, J.H., 2012. Regional stream richness, hydrological characteristics and local species richness of assemblages of North American stream fishes. Freshw. Biol. 57, 2367-2377. 
O'Brien, G.C., Dickens, C., Hines, E., Wepener, V., Stassen, R., Landis, W.G., 2017. A regiona scale ecological risk framework for environmental flow evaluations. Hydrol. Earth Syst. Sci. Discuss. https://doi.org/10.5194/hess-2017-37.

Olden, J.D., Poff, N.L., 2003. Redundancy and the choice of hydrologic indices for characterizing streamflow regimes. River Res. Appl. 19, 101-121.

Omernik, J.M., Griffith, G.E., 2014. Ecoregions of the conterminous United States: evolution of a hierarchical spatial framework. Environ. Manag. 54, 1249-1266.

Pallares, S., Velasco, J., Millan, A., Bilton, D.T., Arribas, P., 2016. Aquatic insects dealing with dehydration: do desiccation resistance traits differ in species with contrasting habitat preferences? PeerJ 2016, e2382. https://doi.org/10.7717/peerj.2382.

Palmer, W., 1965. Meterolological drought. Research Paper No. 45. U.S. Department of Commerce Weather Bureau (February 1965 (58 pgs)).

Petersen, J.C., Adamski, J.C., Bell, R.W., Davis, J.V., Femmer, S.R., Freiwald, D.A., Joseph, R.L. 2005. Water Quality in the Ozark Plateaus. National Water Quality Assessment Program Available online at. http://ar.water.usgs.gov/nawqa/ozark/setting.html.

Poff, N.L., 1992. Regional hydrologic response to climate change: an ecological perspective. In: Firth, P., Staurt, G. (Eds.), Global Climate Change and Freshwater Ecosystems Springer-Verlag, New York, pp. 88-115.

Poff, N.L., 2017. Beyond the natural flow regime? Broadening the hydro-ecological foundation to meet environmental flows challenges in a non-stationary world. Freshw. Biol. 2017, 1-11.

Poff, N.L., Allan, J.D., 1995. Functional organization of stream fish assemblages in relation to hydrologic variability. Ecology 76 (2), 606-627.

Poff, N.L., Zimmerman, J.K.H., 2010. Ecological responses to altered flow regimes: a literature review to inform the science and management of environmental flows. Freshw. Biol. 55, 194-205.

Poff, N.L., Allan, J.D., Bain, M.B., Karr, J.R., Prestegaard, K.L., Richter, B.D., Sparks, R.E., Stromberg, J.C., 1997. The natural flow regime: a paradigm for river conservation and restoration. Bioscience 47, 769-784.

Poff, N.L., Olden, J.D., Pepin, D.M., Bledsoe, B.P., 2006. Placing global stream flow variability in geographic and geomorphic contexts. River Res. Appl. 22, 149-166.

Poff, N.L., Richter, B.D., Arthington, A.H., Bunn, S.E., Naiman, R.J., Kendy, E., Acreman, M. Apse, C., Bledsoe, B.P., Freeman, M.C., Henriksen, J., Jacobson, R.B., Kennen, J.G., Merritt, D.M., O'Keeffe, J.H., Olden, J.D., Rogers, K., Tharme, R.E., Warner, A., 2010 The ecological limits of hydrologic alteration (ELOHA): a new framework for developing regional environmental flow standards. Freshw. Biol. 55, 147-170.

Pregler, K.C., Vokoun, J.C., Jensen, T., Hagstrom, N., 2015. Using multimethod occupancy estimation models to quantify gear differences in detection probabilities: is backpack electrofishing missing occurrences for a species of concern? Trans. Am. Fish. Soc. 144, 89-95.

Rabeni, C.F., Collier, K.J., Parkyn, S.M., Hicks, B.J., 1997. Evaluating techniques for sampling stream crayfish (Paranephrops planifrons). N. Z. J. Mar. Freshw. Res. 31, 693-700.

Robison, H.W., Buchanan, T.M., 1988. Fishes of Arkansas. University of Arkansas Press, Fayetteville, Arkansas.

Rolls, R.J., Arthington, A.H., 2014. How do low magnitudes of hydrologic alteration impact riverine fish populations and assemblage characteristics? Ecol. Indic. 39, 179-188.

Rolls, R.J., Leigh, C., Sheldon, F., 2012. Mechanistic effects of low-flow hydrology on riverine ecosystems: ecological principles and consequences of alteration. Freshw. Sci. 31, 1163-1186.
Scott, J.T., Haggard, B.E., Sharpley, A.N., Romeis, J.J., 2011. Change point analysis of phosphorus trends in the Illinois River (Oklahoma) demonstrates the effects of watershed management. J. Environ. Qual. 40, 1249-1256.

Sengupta, A., Adams, S.K., Bledsoe, B.P., Stein, E.D., McCune, K.S., Mazor, R.D., 2018. Tools for managing hydrologic alteration on a regional scale: estimating changes in flow characteristics at ungagued sites. Freshw. Biol. 2018, 1-17. https://doi.org/10.1111/ fwb.13074.

Sondergaard, M., Jeppesen, E., 2007. Anthropogenic impacts on lake and stream ecosystems, and approaches to restoration. J. Appl. Ecol. 44 (6), 1089-1094. https://doi. org/10.1111/j.1365-2664.2007.01426.x.

Stenroth, K., Bohman, I., Herrman, J., 2010. Drought impact on stream detritivores: experimental effects on leaf litter breakdown and life cycles. Hydrobiologia 652 (1), 247-254.

Stubbington, R., 2012. The hyporheic zone as an invertebrate refuge: a review of variability in space, time, taxa, and behavior. Mar. Freshw. Res. 63 (4), 293-311.

ter Braak, C.J.F., 1995. Ordination. In: Jongman, R.H.G., ter Braak, C.J.F., Van Tongeren, O.F.R. (Eds.), Data Analysis in Community and Landscape Ecology. Cambridge University Press, New York, pp. 91-173.

ter Braak, C.J.F., Smilauer, P., 2002. CANOCO Reference Manual and User's Guide to Canoco for Windows: Software for Canonical Community Ordination (Version 4.5) Microcomputer Power: Ithaca, New York.

[TNC-OEAT] The Nature Conservancy, Ozarks Ecoregional Assessment Team, 2003. Ozarks Ecoregional Conservation Assessment. The Nature Conservancy, Midwestern Resource Office Minneapolis, Minnesota.

Ward, J.V., 1998. Riverine landscapes: biodiversity patterns, disturbance regimes, and aquatic conservation. Biol. Conserv. 83, 269-278.

Ward, J.V., Stanford, J.A., 1995. Ecological connectivity in alluvial river ecosystems and its disruption by flow regulation. Regul. Rivers Res. Manag. 15, 125-139.

Warfe, D.M. Hardie, S.A Uytendaal, A.R, Bobbi, C., Barmuta, LA. 2014. The ecology of rivers with contrasting flow regimes: identifying indicators for setting environmental flows. Freshw. Biol. 59, 2064-2080.

Wickson, S., Chester, E.T., Robson, B.J., 2012. Aestivation provides flexible mechanisms for survival of stream drying in a larval trichopteran (Leptoceridae). Mar. Freshw. Res. 63, 821-826

Wisniewski, J., Rankin, N.M., Weiler, D.A., Strickland, B.A., Chandler, H.C., 2013. Occupancy and detection of benthic macroinvertebrates: a case study of unionids in the lower Flint River, Georgia, USA. Freshwater Science 32 (4), 1122-1135.

Wood, P.J., Boulton, A.J., Little, S., Stubbington, R., 2010. Is the hyporheic zone a refugium for aquatic macroinvertebrates during severe low flow conditions? Fundam. Appl. Limnol. 176 (4), 377-390.

Xenopolous, M.A., Lodge, D.M., Alcamo, J., Marker, M., Schulze, K., Van Vuuren, D.P., 2005. Scenarios of freshwater fish extinctions from climate change and water withdrawal. Glob. Chang. Biol. 11, 1557-1564.

Zhang, Y., Arthington, A.H., Burn, S.E., Mackay, S., Xia, J., Kennard, M., 2012. Classification of flow regimes for environmental flow assessment in regulated rivers: the Huai River basin, China. River Res. Appl. 28, 989-1005.

Zimmerman, J.K.H., Carlisle, D.M., Klausmeyer, K.R., Grantham, T.E., Brown, L.R., Howard, J.K., 2018. Patterns and magnitude of flow alteration in California, USA. Freshw. Biol. 2017, 1-15. https://doi.org/10.1111/fwb.13058. 